\title{
Use of Phosphite Salts in Laboratory and Semicommercial Tests to Control Citrus Postharvest Decay
}

L. Cerioni and V. A. Rapisarda, Instituto Superior de Investigaciones Biológicas-INSIBIO (CONICET-UNT), Chacabuco 461, Tucumán, CP T4000ILI, Argentina; J. Doctor, FGS Packing Services, Exeter, CA 93221; S. Fikkert, Plant Protectants, Inc., Visalia, CA 93291; T. Ruiz and R. Fassel, Pace International Co., Seattle 98101; and J. L. Smilanick, United States Department of AgricultureAgricultural Research Service, San Joaquin Valley Agricultural Sciences Center, Parlier, CA 93648

\begin{abstract}
Cerioni, L., Rapisarda, V. A., Doctor, J., Fikkert, S., Ruiz, T., Fassel, R., and Smilanick, J. L. 2013. Use of phosphite salts in laboratory and semicommercial tests to control citrus postharvest decay. Plant Dis. 97:201-212.

Potassium phosphite (KP) concentrations that inhibited the germination of 50\% of Penicillium digitatum conidia were 229, 334, 360, 469, 498 , or $580 \mathrm{mg} / \mathrm{liter}$ at $\mathrm{pH} 3,4,5,6,7$, or 8 , respectively. Increasing phosphate content in media reduced phosphite toxicity. To control green or blue mold, fruit were inoculated with $P$. digitatum or $P$. italicum, then immersed $24 \mathrm{~h}$ later in $\mathrm{KP}$, calcium phosphite $(\mathrm{CaP})$, sodium carbonate, sodium bicarbonate, or potassium sorbate for $1 \mathrm{~min}$ at 20 $\mathrm{g} /$ liter for each at 25 or $50^{\circ} \mathrm{C}$. Mold incidence was lowest after potassium sorbate, $\mathrm{CaP}$, or $\mathrm{KP}$ treatments at $50^{\circ} \mathrm{C}$. $\mathrm{CaP}$ was often more

more effective when fruit were stored at 10 or $15^{\circ} \mathrm{C}$ after treatment compared with $20^{\circ} \mathrm{C}$. Acceptable levels of control were achieved only when KP was used in heated solutions or with fungicides. KP was compatible with imazalil (IMZ) and other fungicides and improved their effectiveness. KP increased thiabendazole or IMZ residues slightly. Phosphite residues did not change during storage for 3 weeks, except they declined when KP was applied with IMZ. KP caused no visible injuries or alteration in the rate of color change of citrus fruit in air or ethylene at $5 \mu \mathrm{l} /$ liter.
\end{abstract} effective than KP but left a white residue on fruit. KP was significantly
Significant losses occur after harvest, during storage and marketing of citrus fruit, primarily due to green mold, caused by Penicillium digitatum. Blue mold, caused by $P$. italicum, also causes fruit losses but is of lesser importance $(16,45)$. Currently, both diseases are commonly controlled by postharvest applications of sodium bicarbonate (SBC), imazalil (IMZ), thiabendazole (TBZ), pyrimethanil (PYR), azoxystrobin (AZO), fludioxonil (FLUD), or sodium o-phenylphenate $(27,45,46,49,50)$. Concerns about how fungicides may impact human and environmental health and the widespread occurrence of fungicide-resistant isolates of $P$. digitatum $(26,28)$ have stimulated the search for alternative treatments.

SBC partially controls green and blue molds of citrus fruit $(6,36,46)$, and its addition to IMZ (45), PYR (50), or TBZ (47) improved their performance. The addition of SBC facilitates the use of reduced fungicide rates, which decreases costs and improves control of fungicide-resistant isolates of $P$. digitatum. SBC can be used in sequence with other treatments, such as biological control or hot water, to improve their efficacy $(37,39)$. SBC is relatively inexpensive and approved for use for "organic" growers, and its residues are exempt from regulation. However, disposal of SBC raises regulatory issues in some locations, because of its high electrical conductivity, high $\mathrm{pH}$, and sodium content. All three factors can make disposal of used solutions difficult. Therefore, compounds that could improve fungicide performance as SBC

Corresponding author: J. L. Smilanick,

E-mail: Joe.Smilanick@ars.usda.gov

Mention of trade names or commercial products in this publication is solely for the purpose of providing specific information and does not imply recommendation or endorsement by the United States Department of Agriculture (USDA). USDA is an equal opportunity employer.

Accepted for publication 23 August 2012.

http://dx.doi.org/10.1094/PDIS-03-12-0299-RE

This article is in the public domain and not copyrightable. It may be freely reprinted with customary crediting of the source. The American Phytopathological Society, 2013. does yet avoid or minimize these disposal problems would be valuable. In prior work, we found that potassium sorbate (48) and calcium polysulfide (51) were effective replacements for SBC that solved disposal problems of spent solutions. The purpose for this work was to find a similar alternative.

Phosphorous acid and its phosphite salts merit evaluation as substitutes for conventional postharvest fungicides. Phosphite solutions can be manufactured to be devoid of sodium and have a neutral $\mathrm{pH}$, which eliminates two important water-quality problems of SBC or sodium carbonate. Soil disposal of used phosphite solutions is a feasible route of disposal because many phosphite products are registered as fertilizers. Phosphites oxidize slowly to phosphates in soil $(1,30)$. They are exempt from residue tolerances in the United States (55), and two commercial potassium phosphite formulations are registered for postharvest use in the United States (KPhos; Pace International, and Fungi-Phite; Plant Protectants Inc.). Phosphites offer another significant advantage over other alternative treatments in that they control postharvest brown rot, caused by several Phytophthora spp. $(11,19)$. Brown rot is not controlled by the currently registered fungicides or their alternatives and, in some wet seasons in California, citrus fruit losses from brown rot become significant. The compatibility of phosphites with fungicides needs evaluation, to determine whether they can be used with fungicides now in use and if there are useful interactions present. Rosenberger et al. (42) reported that control of flyspeck of apple, caused by Zygophiala jamaicensis, by captan or thiophanate methyl was significantly improved by the addition of phosphite, although it did not improve control of fruit rot due to black rot caused by Botryospheria sp. or sooty blotch. This report indicates the potential synergism between phosphite salts and fungicides.

Phosphorous acid $\left(\mathrm{H}_{3} \mathrm{PO}_{3}\right)$ in solution is in equilibrium with its tautomeric form, phosphonic acid. Phosphonates or phosphites, anionic forms of phosphonic or phosphorous acids, respectively, are used in formulations containing either the aluminum salt of ethyl-phosphonate (fosetyl-aluminum) or the potassium or calcium salt of phosphite $(12,22,23,33)$. Many phosphite products are available today as fungicides, while others are marketed as fertilizers or "defense stimulators". Although foliar phosphite applications 
increased flower numbers and yields on 'Valencia' orange, controversy still exists as to their use as fertilizers, because benefits from phosphite applications may result from the control of pathogens, among other mechanisms (4). Phosphites do not supply phosphorus directly to plants. Although the phosphite cation is mobile and available, it requires oxidation to phosphate prior to use by plants and this process is mediated by microbes $(31,32,54)$. Phosphites are effective for the control of diseases caused by oomycetes (Phytophthora, Plasmopara, and Pythium spp. and others) that are particularly susceptible to inhibition by phosphite $(9,10,14$, $24,33,34)$. Few reports describe control of true fungi by phosphites. Bassay Blum et al. (7) reported that immersion of apple fruit in phosphite solutions controlled blue mold, caused by P. expansum. Amiri and Bompeix (5) reported that potassium phosphite inhibited conidial germination and mycelial growth of $P$. expansum and it was more effective when applied in heated solutions. Treatment with potassium phosphite at $2 \mathrm{~g} /$ liter and $50^{\circ} \mathrm{C}$ for $3 \mathrm{~min}$ completely suppressed blue mold in 'Elstar' apple fruit after 7 days of storage at $20^{\circ} \mathrm{C}$. This regime is commercially feasible for the processing of many kinds of fruit.

The objectives of this study were to (i) determine the effectiveness of phosphite salts for controlling citrus green and blue molds; (ii) quantify the effect of heat, phosphite concentrations, $\mathrm{pH}$, and storage temperature on the efficacy of the treatments; (iii) evaluate the influence of phosphite salts on the performance of other citrus postharvest fungicides; (iv) evaluate the influence of the interval on the performance of IMZ when mixed with potassium or calcium salts of phosphite; and (v) determine how the addition of potassium phosphite to the most common commercial fungicides (IMZ or TBZ) influences the levels and persistence of fungicide residues on fruit.

\section{Materials and Methods}

Chemical sources and phosphite formulations. Unless stated otherwise, all reagents were obtained from Sigma-Aldrich. Four sources of phosphite were used: (i) phosphorous acid (99.9\%); (ii) commercial formulation A, potassium phosphite $(54.5 \%$ potassium phosphite, KPhos; Pace International); (iii) commercial formulation B (45.5\% potassium phosphite, Fungi-Phite; Plant Protectants Inc.); and (iv) commercial formulation $C$ ( $42.5 \%$ calcium phosphite, Calci-Phite; Biagro Western Sales, Inc.).

Pathogen culture. Two isolates of $P$. digitatum (IMZ-sensitive PD90 and IMZ-resistant D201) and one isolate of P. italicum (PI105) were cultured for 1 to 2 weeks on potato dextrose agar (Difco Laboratories) at $25^{\circ} \mathrm{C}$. Both pathogens were isolated from infected lemon from citrus packinghouses in California. Isolates PD90 and PI105 can be controlled by typical commercial IMZ applications in California packinghouses, whereas isolate D201 has approximately a 10-fold resistance to IMZ and is only controlled by IMZ application rates that are so high that the resulting residues may exceed Environmental Protection Agency-approved tolerances (28). Conidia were harvested by adding $5 \mathrm{ml}$ of sterile reverseosmosis water $\left(\mathrm{roH}_{2} \mathrm{O}\right)$ containing $0.05 \%$ (vol/vol) Triton X-100 into the petri dish. Colonies were rubbed with a sterile glass rod, and the resulting conidial suspension was passed through two layers of cheesecloth. The suspension was diluted with $\mathrm{roH}_{2} \mathrm{O}$ to an absorbance of 0.1 at $425 \mathrm{~nm}$ as measured with a spectrophotometer and a density containing $1 \times 10^{6}$ conidia/ml (15), unless stated otherwise.

Conidial germination assays. Conidial germination of $P$. digitatum (isolate PD90) in media containing several concentrations of $\mathrm{H}_{3} \mathrm{PO}_{3}$ at different $\mathrm{pH}$ values was determined. The germination medium, buffered potato-dextrose broth (PDB-b), was prepared by placing $96 \mathrm{~g}$ of PDB (Difco Laboratories) and $20 \mathrm{mM}$ each of glycylglycine and disodium phosphate in 1 liter of $\mathrm{roH}_{2} \mathrm{O}$. The $\mathrm{pH}$ of the medium was adjusted to $3,4,5,6,7$, or 8 , with $1 \mathrm{~N}$ $\mathrm{KOH}$ or $\mathrm{HCl}$. The phosphate concentration in this medium greatly exceeded what is needed for the growth of $P$. digitatum (8) and other fungi (21). Sterile dishes with six macrowells (Corning Glass Works) with a capacity of $10 \mathrm{ml} /$ well were used. In each well, 2.5 $\mathrm{ml}$ of PDB-b, $\mathrm{H}_{3} \mathrm{PO}_{3}$ at various concentrations, $0.1 \mathrm{ml}$ of conidial suspension, and $\mathrm{roH}_{2} \mathrm{O}$ were added to a final volume of $5.0 \mathrm{ml}$. Actual $\mathrm{H}_{3} \mathrm{PO}_{3}$ concentrations were $0,125,250,500,750,1,000$, 1,250 , or $1,500 \mathrm{mg} /$ liter. After $24 \mathrm{~h}$ of incubation at $25^{\circ} \mathrm{C}, 100$ to 150 conidia were counted in each well by observation $(\times 200)$ using an inverted compound microscope, and the percentage of germinated conidia was calculated. Phosphite concentrations that inhibited germination of $50 \%\left(\mathrm{EC}_{50}\right)$ and $99 \%\left(\mathrm{EC}_{99}\right)$ of the conidia were determined. All experiments were performed twice.

The influence of phosphorus on phosphite toxicity was determined by utilizing the methods as described above, except that modified Pratt's medium (53) was used with final $\mathrm{H}_{3} \mathrm{PO}_{3}$ concentrations of $0.5,0.75,1,1.25$, or $1.5 \mathrm{~g} / \mathrm{liter}$ and final phosphate concentrations of $0,0.1$, or $10 \mathrm{mM}$. Phosphate was prepared from $\mathrm{KH}_{2} \mathrm{PO}_{3}$ and the final $\mathrm{pH}$ of the medium was 6.0.

Fruit inoculation. Freshly harvested lemon ('Eureka'), mandarin orange ('WMurcott', 'Marisol', or 'Clementina de Nule'), navel orange ('Atwood', 'Barnfield', or 'Fukimoto'), or seeded orange (Valencia) were used. They were selected because they are popular cultivars that were mature and available at the time the tests were conducted. Postharvest decay can differ greatly among cultivars (38). Control of decay on mandarin oranges is generally more difficult than other citrus cultivars (37). The fruit were randomized by dividing them into groups equal to the number of treatments being evaluated; equal numbers of fruit from each harvest box were assigned to every treatment. Conidial suspensions of $P$. digitatum and $P$. italicum were prepared as described previously and a concentration of $1 \times 10^{6} \mathrm{conidia} / \mathrm{ml}$ was used to inoculate the fruit $24 \mathrm{~h}$ before treatments were applied (15). The tip of a stainless steel rod, $1 \mathrm{~mm}$ wide and $2 \mathrm{~mm}$ in length, was immersed in a conidial suspension of the corresponding pathogen and inserted afterward at the equatorial position in the fruit rind. Inoculated fruit were maintained at $20^{\circ} \mathrm{C}$ and $95 \%$ relative humidity $(\mathrm{RH})$ until treatment. In most tests, fruit were inoculated once at a single site with $P$. digitatum or $P$. italicum. In some tests, fruit were inoculated at one end with $P$. digitatum and at the opposite end with $P$. italicum.

Influence of heat, $\mathrm{pH}$, and phosphite concentration on decay control. To examine the effect of heat on the effectiveness of several salt solutions, $P$. digitatum (isolate D201)- and P. italicuminoculated Eureka lemon or P. digitatum (isolate D201)-inoculated WMurcott mandarin orange were immersed for $1 \mathrm{~min}$ in 20 liters of water (control) or potassium phosphite (KP, formulation $\mathrm{B}$ ), calcium phosphite ( $\mathrm{CaP}$, formulation $\mathrm{C})$, sodium carbonate $(\mathrm{SC})$, $\mathrm{SBC}$, or potassium sorbate (KS) solutions at $20 \mathrm{~g} /$ liter in 22-litercapacity stainless steel tanks with a computer-controlled thermostat. The temperature of the solutions was 25 or $50^{\circ} \mathrm{C}\left( \pm 0.5^{\circ} \mathrm{C}\right)$ and each was constantly stirred with a 5 -cm-diameter propeller. Each treatment was applied to four replicates of 27 fruit each. The test was done twice. In the first test, the lemon were not rinsed after treatment whereas, in the second experiment, WMurcott mandarin orange were either not rinsed or briefly immersed in fresh water at $20^{\circ} \mathrm{C}$ after every treatment. A treatment with PYR (Penbotec 400SC; Janssen PMP) at $1 \mathrm{~g} /$ liter was included and these fruit were not rinsed after treatment.

To examine the effect of $\mathrm{pH}$ on phosphite decay control efficacy, $P$. digitatum (isolate PD90)- and P. italicum-inoculated Eureka lemon fruit were immersed for $1 \mathrm{~min}$ in water (control) or buffered solutions that contained KP (formulation A) at $10 \mathrm{~g} /$ liter adjusted

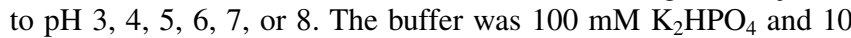
$\mathrm{mM}$ citric acid for the $\mathrm{pH} \mathrm{3,4}$, or $5 \mathrm{KP}$ solutions, and $100 \mathrm{mM}$ $\mathrm{K}_{3} \mathrm{PO}_{4}$ and $10 \mathrm{mM}$ citric acid for $\mathrm{pH} 6,7$, or $8 \mathrm{KP}$ solutions. The $\mathrm{pH}$ was adjusted with concentrated $\mathrm{H}_{2} \mathrm{SO}_{4}, \mathrm{H}_{3} \mathrm{PO}_{4}$, or $\mathrm{KOH}$. Each treatment was applied to five replicates of 20 fruit each. A similar experiment was done with Marisol mandarin orange, with the differences that $20 \mathrm{mM}$ potassium phosphate buffer was used, only $P$. digitatum (isolate PD 90) was used to inoculate the fruit, the KP (formulation A) concentration was $15 \mathrm{~g} / \mathrm{liter}$, and the contact time of the fruit in the solution was 2 min. Each treatment was applied to four replicates of 27 fruit each. 
To examine the effect of temperature and phosphite salt $(\mathrm{CaP}$ or $\mathrm{KP}$, formulations $\mathrm{B}$ or $\mathrm{C}$ ) concentration on effectiveness, $P$. digitatum (isolate D201)-inoculated Barnfield navel orange were immersed for $15 \mathrm{~s}$ in water (control) or $\mathrm{CaP}$ or $\mathrm{KP}$ solutions at 5 or 15 $\mathrm{g} /$ liter and $21,41,46,52$, or $57^{\circ} \mathrm{C}\left( \pm 0.5^{\circ} \mathrm{C}\right)$. The fruit were not rinsed after treatment. Each treatment was applied to three replicates of 20 fruit each with two inoculations sites per fruit. In a second experiment evaluating both KP concentration and temperature, $P$. digitatum (isolate PD90)- and $P$. italicum-inoculated Eureka lemon fruit were immersed for $1 \mathrm{~min}$ in water (control) or in 20 liters of KP (formulation A) at 5, 10, or $20 \mathrm{~g} /$ liter and 25 or $50^{\circ} \mathrm{C}\left( \pm 0.5^{\circ} \mathrm{C}\right)$. In this test, a treatment with IMZ (Fungaflor 500 EC, 44.6\% IMZ; Janssen PMP) at $0.2 \mathrm{~g} /$ liter and $50^{\circ} \mathrm{C}$ during $15 \mathrm{~s}$ was included. After treatment, unrinsed fruit were placed into cavity trays and stored for 1 or 2 weeks at $20^{\circ} \mathrm{C}$ and $95 \% \mathrm{RH}$, and then the number of infected fruit was counted. Each treatment was applied to five replicates of 20 fruit each.

Influence of storage temperature on effectiveness of phosphites salts. Clementina de Nule mandarin orange or Fukimoto navel orange fruit were inoculated with $P$. digitatum (isolate PD90) and $P$. italicum as previously described, and were then immersed in $\mathrm{KP}$ (formulation A) at $20 \mathrm{~g} / \mathrm{liter}$ and 25 or $50^{\circ} \mathrm{C}$ $\left( \pm 0.5^{\circ} \mathrm{C}\right)$ for $60 \mathrm{~s}$. The fruit were not rinsed after treatment. Each treatment was applied to three replicates of 20 fruit each. After treatment, the fruit were packed into cavity trays and stored for 3 weeks at 10,15 , or $20^{\circ} \mathrm{C}$ and $95 \% \mathrm{RH}$. Prior preliminary tests indicated that the number of fruit that became infected after inoculation did not increase significantly after 3 weeks of storage at these temperatures.

Evaluation of phosphite salts combined with conventional postharvest fungicides. Eureka lemon fruit were inoculated with $P$. digitatum (isolate D201), and immersed for $30 \mathrm{~s}$ in $25^{\circ} \mathrm{C}$ solutions containing either IMZ at $0.5 \mathrm{~g} / \mathrm{liter}$, TBZ (Sealbrite, $98.5 \%$ thiabendazole; EcoScience Corp.) at $25 \mathrm{mg} / \mathrm{liter}$, PYR at 25 $\mathrm{mg} / \mathrm{liter}$, or a mixture of FLUD + AZO that contained each (Graduate $\mathrm{A}+, 20.6 \%$ fludioxonil and $20.6 \%$ azoxystrobin; Syngenta Crop Protection, Inc.) at $20 \mathrm{mg} / \mathrm{liter}$. They were applied alone or mixed with KP (formulation A) at $4 \mathrm{~g} /$ liter. The fruit were not rinsed after treatment. For FLUD + AZO treatment, fruit were inoculated $12 \mathrm{~h}$ before treatments were applied. After treatment, the fruit were packed into cavity trays, stored for 17 days at $10^{\circ} \mathrm{C}$ and $95 \% \mathrm{RH}$, and then evaluated for decay. Each treatment was applied to four replicates of 27 lemon fruit each. In a second test, Eureka lemon fruit inoculated with $P$. digitatum (isolate D201) were immersed for $2 \mathrm{~min}$ at 20 or $40^{\circ} \mathrm{C}\left( \pm 0.5^{\circ} \mathrm{C}\right)$ in either IMZ at $0.2 \mathrm{~g} /$ liter, $\mathrm{KP}$ (formulation B) at $10 \mathrm{~g} / \mathrm{liter}, \mathrm{SBC}$ at $20 \mathrm{~g} / \mathrm{liter}$, a mixture of $\mathrm{KP}+$ $\mathrm{IMZ}$, or a mixture of $\mathrm{KP}+\mathrm{SBC}$. After treatment, unrinsed fruit were stored for 21 days at $20^{\circ} \mathrm{C}$, and then the number of infected fruit was counted. Each treatment was applied to four replicates of 27 fruit each.

In a large commercial test using commercial packing equipment, Eureka lemon, WMurcott mandarin orange, and Atwood navel orange were inoculated with $P$. digitatum (isolate D201 or PD90) at $1 \times 10^{5}$ conidia $/ \mathrm{ml}$. After 18 to $20 \mathrm{~h}$ at $20^{\circ} \mathrm{C}$, the fruit were treated with either KP (formulation B) at $15 \mathrm{~g} /$ liter, $\mathrm{CaP}$ (formulation C) at $15 \mathrm{~g} /$ liter, or IMZ alone by passing the fruit down a packing line where they were drenched for $15 \mathrm{~s}$ by 16 solid cone nozzles, each delivering 2.1 liter/min over a 1.5-m-long bed of 25 brushes (Tufted Polycor; Industrial Brush Co.) rotating at 80 revolutions $/ \mathrm{min}$. The IMZ concentration applied was $0.05 \mathrm{~g} / \mathrm{liter}$ for the IMZ-sensitive isolate and $0.5 \mathrm{~g} /$ liter for the IMZ-resistant isolate. The solution temperature was $46^{\circ} \mathrm{C}$. After treatment, unrinsed fruit were dried for $2 \mathrm{~min}$ at $60^{\circ} \mathrm{C}$ in a commercial fruit dryer, packed into cartons with cavity trays to prevent fruit-to-fruit contact, and stored for 3 weeks at $10^{\circ} \mathrm{C}$. Each treatment was applied to three or four replicates of approximately 50 to 75 fruit each.

Influence of inoculation time on KP and IMZ effectiveness. To evaluate the curative and protective activities of KP and IMZ, Eureka lemon fruit were inoculated with $P$. digitatum (isolate PD90) near the stem attachment point and again on the distal end with $P$. italicum. Inoculations were done either 48 or $24 \mathrm{~h}$ before treatments were applied or $24,48,72,96$, or $120 \mathrm{~h}$ after treatments were applied. The treatments included $30 \mathrm{~s}$ of immersion at $25^{\circ} \mathrm{C}$ in water alone, IMZ at $0.5 \mathrm{~g} /$ liter, $\mathrm{KP}$ (formulation A) at $5 \mathrm{~g} /$ liter, or IMZ at $0.5 \mathrm{~g} /$ liter plus $\mathrm{KP}$ at $5 \mathrm{~g} /$ liter. After treatment, unrinsed fruit were stored for 14 days at $20^{\circ} \mathrm{C}$, before the number of infected fruit was counted. Each treatment was applied to five replicates of 20 lemon each. In a second test, Eureka lemon or Valencia orange fruit were dipped for $30 \mathrm{~s}$ at $25^{\circ} \mathrm{C}$ in IMZ at $0.5 \mathrm{~g} /$ liter, $\mathrm{KP}$ (formulation A) at $5 \mathrm{~g} /$ liter, or a mixture of both. After 5 days at $10^{\circ} \mathrm{C}$, the lemon fruit were all inoculated with $1 \times 10^{4}$ conidia $/ \mathrm{ml}$ and the orange with $1 \times 10^{5}$ conidia/ml using $P$. digitatum isolate D201. The fruit were not rinsed after treatment and stored for 14 days at $20^{\circ} \mathrm{C}$; then, the number of infected fruit was counted. Each treatment was applied to five replicates of 20 orange fruit or four replicates of 27 lemon fruit each.

Fruit tissue phosphite, phosphate, and fungicide analysis. Analyses were conducted to determine the influence of phosphite treatment on the phosphite and phosphate residues on fruit, and whether fungicides residues were altered when applied in mixtures with phosphite. Atwood orange fruit were immersed for $30 \mathrm{~s}$ in IMZ ( $0.4 \mathrm{~g} /$ liter $)$ or TBZ $(0.4 \mathrm{~g} /$ liter $)$ solutions at 25 or $50^{\circ} \mathrm{C}$, either alone or with KP (formulation B) at $20 \mathrm{~g} /$ liter. After treatment, the fruit were not rinsed and the residues of each fungicide and contents of phosphite and phosphate were determined within 2 days and again after 3 weeks of storage at $5^{\circ} \mathrm{C}$. Each treatment analyzed included four replicate of five fruit each. Subsamples from the five fruit were pooled to create a single sample for analysis from each replicate. The test was done once. Fungicide residues were reported as milligrams per kilogram fresh weight. For IMZ and TBZ analysis, the whole fruit were extracted for $1 \mathrm{~h}$ with ethyl acetate followed by gas chromatography by the method of Yamazaki and Ninomiya (56). The detection limit was less than $0.1 \mathrm{mg} / \mathrm{kg}$ and the efficiency of recovery exceeded $95 \%$ for both fungicides. The phosphate and phosphite concentrations in the orange rind tissue were determined using the high-performance ion chromatographic method of Roos et al. (41), with some modifications. Phosphite and phosphate contamination was minimized by wiping all tools and surfaces with dilute $\mathrm{HCl}$. The top $2 \mathrm{~mm}$ of the rind of the fruit was scraped to produce tissue fragments approximately $1 \mathrm{~mm}$ in size. Only flavedo tissue was collected. A 5-g portion of the flavedo tissue fragments was placed in a glass jar and frozen at $-16^{\circ} \mathrm{C}$ for $8 \mathrm{~h}$. Then, $50 \mathrm{ml}$ of $40 \mathrm{mM} \mathrm{HCl}$ was added to the jar and the sample and extract were shaken vigorously 50 times. The jar was placed at $5^{\circ} \mathrm{C}$ for $24 \mathrm{~h}$ so particulates could condense and precipitate; then, $2 \mathrm{ml}$ of the extract was collected and passed through a $0.2-\mu \mathrm{m}$ pore size Teflon filter and injected into an HPLC (Shimadzu) with a column recommended for anion chromatography (STAR-ION-A 300, 100 by $4.6 \mathrm{~mm}$; Phenomenex), using a mobile phase of $100 \mathrm{mM}$ succinic acid with $0.02 \%$ (wt/vol) sodium azide, and a conductivity detector. Standards containing phosphorous acid and potassium dihydrogen orthophosphate were prepared. Tissue phosphite and fungicide contents were expressed as milligrams per kilogram fresh weight.

Influence of postharvest treatments with KP on fruit rind color. The test was done with freshly harvested, non-waxed, Eureka lemon, WMurcott mandarin orange, and Atwood navel orange from the University of California Lindcove Research and Extension Center, Exeter. Fruit that were dark green in color were either not treated (dry control), immersed for $60 \mathrm{~s}$ in water at 25 or $50^{\circ} \mathrm{C}$ (wet control), or immersed for $60 \mathrm{~s}$ in $\mathrm{KP}$ (formulation A) at 20 g/liter and 25 or $50^{\circ} \mathrm{C}$. Fruit were not rinsed after treatment and immediately placed at $20^{\circ} \mathrm{C}$ and 90 to $95 \%$ relative humidity in either air or air adjusted to contain ethylene at $5 \mu \mathrm{l} /$ liter. The test was done three times, each time with four replicates of 10 fruit each The rate of color change during ethylene degreening was measured with a colorimeter (CR400; Minolta Corp.). Measurements were made at the time of treatments and weekly thereafter until most all green color was absent. $\mathrm{L}^{*}$ and calculated hue angle values were used for statistical analysis (35). 
Statistical analysis. The concentrations of phosphite in PDB-b that resulted in 50 or $99 \%$ reductions in conidial germination $\left(\mathrm{EC}_{50}\right.$ or $\mathrm{EC}_{99}$, respectively) were estimated by probit analysis (SPSS Statistics 17.0). Disease incidence, color values, fungicide residues, and phosphite and phosphate contents were analyzed by using a one- or two-way analysis of variance (ANOVA) followed by Tukey's honestly significant difference (HSD) test, or Fisher' protected least significant difference was calculated at $P=0.05$ (SPSS Statistics 17.0). Statistical significance values indicated in the prose may refer to an ANOVA applied but not shown. Disease
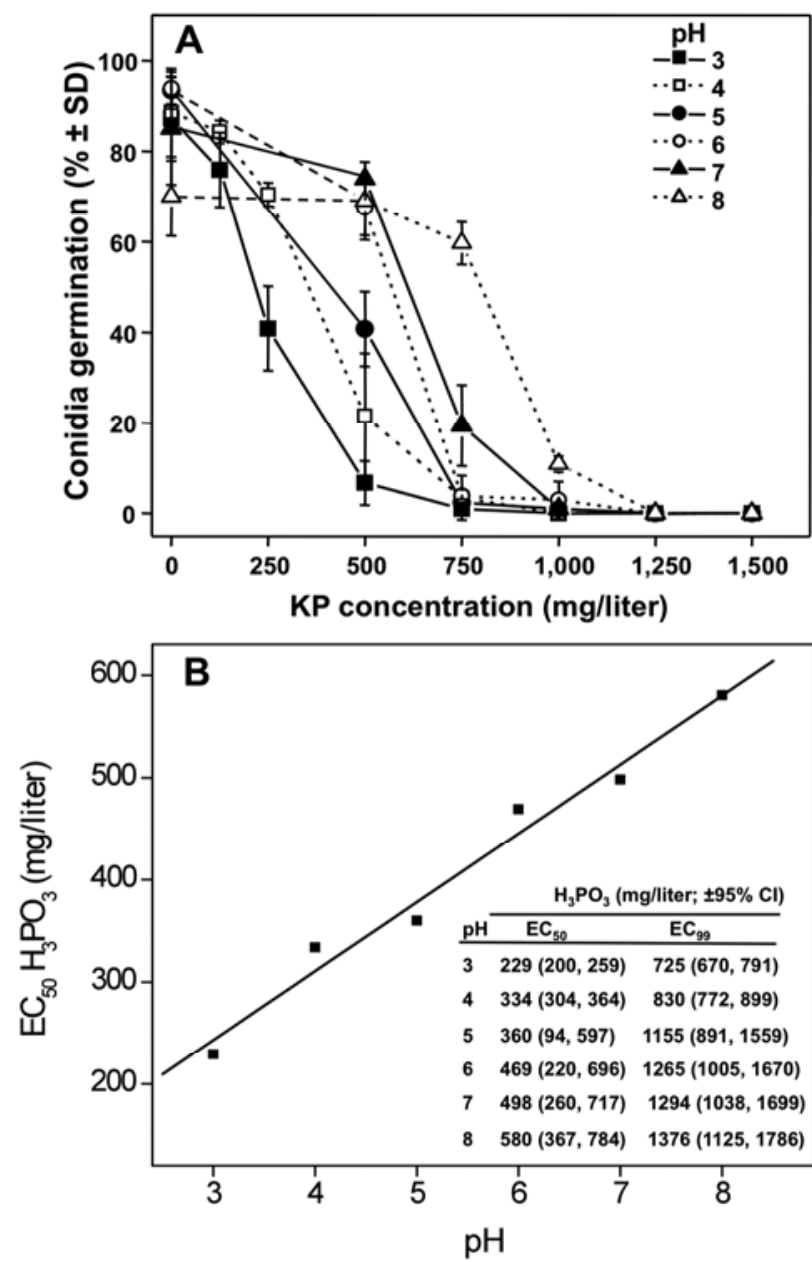

Fig. 1. Germination of conidia of Penicillium digitatum (isolate PD90) in buffered potato dextrose broth (PDB-b) containing different concentrations of phosphorous acid at $\mathrm{pH} 3,4,5,6,7$, or 8 . A, Germination was determined after $24 \mathrm{~h}$ at $25^{\circ} \mathrm{C}$. Each value is the mean of two replicates of 100 to 150 conidia each. B, Effective concentrations of phosphorous acid in PDB-b at pH 3, 4, 5, 6, 7, or 8 to inhibit germination of $50 \%\left(\mathrm{EC}_{50}\right)$ or $99 \%\left(\mathrm{EC}_{99}\right)$ of conidia of $P$. digitatum exposed to phosphorous acid for $24 \mathrm{~h}$ at $25^{\circ} \mathrm{C}$. Values in parenthesis indicate upper and lower $95 \%$ fiducial limits. incidence values among citrus fruit were arcsin transformed and residue contents were $\log _{10}$ transformed before analysis to improve homogeneity of variance. Actual values are shown.

\section{Results}

Evaluation of phosphite salts on conidial germination. Germination of conidia of $P$. digitatum (isolate PD90) was more than $90 \%$ in PDB-b without phosphite amendment from $\mathrm{pH} 3$ to 7 whereas, at $\mathrm{pH} 8$, the germination declined to $70 \%$. Phosphite inhibitory activity was greater at lower $\mathrm{pH}$, being approximately twice as toxic at $\mathrm{pH} 3$ as at $\mathrm{pH} 7$ (Fig. 1A). The $\mathrm{EC}_{50}$ values of $\mathrm{H}_{3} \mathrm{PO}_{3}$ were $229 \mathrm{mg} /$ liter at $\mathrm{pH} 3$ and $498 \mathrm{mg} /$ liter at $\mathrm{pH}$ 7. The $\mathrm{EC}_{99}$ values of $\mathrm{H}_{3} \mathrm{PO}_{3}$ were $725 \mathrm{mg} / \mathrm{liter}$ at $\mathrm{pH} 3$ and $1,290 \mathrm{mg} / \mathrm{liter}$ at $\mathrm{pH} 7$ (Fig 1B).

Phosphorus content greatly influenced phosphite toxicity to conidia of $P$. digitatum. In Pratt's medium at $\mathrm{pH} 6.0$, conidia did not germinate without phosphorus. When this medium was amended with $0.1 \mathrm{mM}$ phosphorus, more than $90 \%$ of conidia germinated in the control well without phosphite but conidia did not germinate when phosphite was present, even at the lowest concentration of $500 \mathrm{mg} /$ liter. When the medium was amended with $10 \mathrm{mM}$ phosphorus, conidia germinated in the presence of phosphorous acid at 500 or $750 \mathrm{mg} /$ liter but not at $1,000 \mathrm{mg} / \mathrm{liter}$ or higher. Among conidia that germinated, the germ tubes were shorter and thicker and more branched than those in this medium without phosphite.

Effect of salt solution temperature on control of citrus green and blue mold. Increasing the temperature of the treatment solutions increased their effectiveness significantly $(P \leq 0.05$; Table 1$)$. Control of green and blue mold on Eureka lemon by $\mathrm{CaP}$ and $\mathrm{KP}$ solutions was better than sodium carbonate or SBC, particularly when used at $50^{\circ} \mathrm{C}$. Water alone at $50^{\circ} \mathrm{C}$ and $\mathrm{KP}$ at $25^{\circ} \mathrm{C}$ moderately controlled decay in this test (Table 1). ANOVA applied to these data indicated that increasing the temperature of $\mathrm{KP}$ and $\mathrm{CaP}$ solutions increased their effectiveness significantly $(P \leq 0.001)$.

On WMurcott mandarin orange, green mold incidence was lower after $\mathrm{KP}$ or $\mathrm{CaP}$ treatment at either 25 or $50^{\circ} \mathrm{C}$ than potassium sorbate, SBC, or sodium carbonate but it was higher than after PYR treatment (Fig. 2). Water treatment alone at $50^{\circ} \mathrm{C}$ reduced green mold incidence significantly in this experiment. $\mathrm{CaP}$ but none of the other salts left white deposits on the fruit that were not rinsed after treatment. ANOVA applied to these data indicated that increasing the temperature of the treatment solutions increased their effectiveness significantly $(P \leq 0.001)$, whereas the brief rinse after treatment did not $(P=0.486)$.

Influence of $\mathbf{p H}$, heat, and rates on phosphite salts effectiveness. The influence of $\mathrm{pH}$ on the effectiveness of KP to control green mold was small and not significant. The incidence of green mold among Eureka lemon fruit after immersion in buffered water was $100 \%$, while decay after immersion in $\mathrm{KP}$ at $10 \mathrm{~g} / \mathrm{liter}$ and $\mathrm{pH}$ $3,4,5,6,7$, or 8 was $100,91.7,93.3,93.3,92.3$, or $81.7 \%$, respectively, and these percentages were not significantly different from each other or the water treatment. The mean incidence of green mold among Marisol mandarin orange fruit after immersion in buffered water was $99.1 \%$, while decay after immersion in KP at 15 g/liter and $\mathrm{pH} 3,5,7$, or 9 was $66.3,65,57.5$, or $60 \%$, respectively,

Table 1. Green mold and blue mold incidence among 'Eureka' lemon immersed for $1 \mathrm{~min}$ in 25 or $50^{\circ} \mathrm{C}$ salt solutions at $20 \mathrm{~g} /$ liter followed by storage for 1 week at $20^{\circ} \mathrm{C}^{\mathrm{z}}$

\begin{tabular}{|c|c|c|c|c|}
\hline \multirow[b]{2}{*}{ Treatment } & \multicolumn{2}{|c|}{ Green mold incidence $(\% \pm \mathrm{SD})$} & \multicolumn{2}{|c|}{ Blue mold incidence $(\% \pm$ SD) } \\
\hline & $25^{\circ} \mathrm{C}$ & $\mathbf{5 0}^{\circ} \mathbf{C}$ & $25^{\circ} \mathrm{C}$ & $\mathbf{5 0}^{\circ} \mathbf{C}$ \\
\hline Water control & $100.0 \mathrm{a}$ & $58.3 \mathrm{a}$ & $32.1 \mathrm{ab}$ & $23.8 \mathrm{a}$ \\
\hline Sodium carbonate & $53.3 \mathrm{~cd}$ & $35.7 \mathrm{ab}$ & $21.9 \mathrm{bc}$ & $7.1 \mathrm{bc}$ \\
\hline Sodium bicarbonate & 38.1 cde & $32.1 \mathrm{ab}$ & $22.6 \mathrm{bc}$ & $15.5 \mathrm{abc}$ \\
\hline Potassium phosphite & $59.5 \mathrm{c}$ & $16.7 \mathrm{bc}$ & $15.5 \mathrm{bc}$ & $2.4 \mathrm{bc}$ \\
\hline Potassium sorbate & $23.8 \mathrm{e}$ & $6.0 \mathrm{c}$ & $7.1 \mathrm{c}$ & $3.6 \mathrm{bc}$ \\
\hline Calcium phosphite & $35.7 \mathrm{de}$ & $4.8 \mathrm{c}$ & $6.0 \mathrm{c}$ & $1.0 \mathrm{c}$ \\
\hline
\end{tabular}

${ }^{\mathrm{z}}$ Lemon fruit were inoculated with Penicillium digitatum (isolate D201) or P. italicum (isolate PI105) $24 \mathrm{~h}$ before treatment. Each treatment was applied to four replicates of 27 fruit each. Values within columns followed by the same letter are not significantly different according to Tukey's honestly significant difference $(P=0.05)$. SD $=$ standard deviation. 
and these percentages were significantly different from the control but not from each other. The influence of $\mathrm{pH}$ on the effectiveness of KP to control blue mold was also small but some differences were significant. The incidence of blue mold among Eureka lemon fruit after immersion in buffered water was $97.5 \%$, whereas decay after immersion in $\mathrm{KP}$ at $10 \mathrm{~g} / \mathrm{liter}$ and $\mathrm{pH} \mathrm{3,} \mathrm{4,} \mathrm{5,} \mathrm{6,} \mathrm{7,} \mathrm{or} 8$ was $73.3,65,63.3,80,55$, or $55 \%$, respectively, and decay among the $\mathrm{KP}$ treatments was significantly $(P \leq 0.05)$ lower at $\mathrm{pH} 7$ and 8 .

The control of green mold on Barnfield navel orange by $\mathrm{CaP}$ and $\mathrm{KP}$ was improved by heating the solutions and by increasing the phosphite concentration. $\mathrm{KP}$ or $\mathrm{CaP}$ at $15 \mathrm{~g} /$ liter was more effective than $5 \mathrm{~g} /$ liter in controlling green mold (Table 2). In a second experiment, KP treatments at 25 or $50^{\circ} \mathrm{C}$ significantly controlled blue mold on Eureka lemon, particularly at 10 or $20 \mathrm{~g} / \mathrm{liter}$, and were equal in effectiveness to IMZ when heated (Fig. 3A). Green mold incidence on Eureka lemon after treatment with $\mathrm{KP}$ at $25^{\circ} \mathrm{C}$ was high at all rates tested. Heating the solution to $50^{\circ} \mathrm{C}$ resulted in improved control with rates of 10 or $20 \mathrm{~g} / \mathrm{liter}$, and were as effective as IMZ (Fig. 3B). In this test, the influence of temperature was greater than that of concentration in reducing the two molds.

Influence of storage temperature on phosphite effectiveness. Post-treatment storage temperature and the temperature of the solution used to treat the fruit had a large impact the incidence of green and blue mold (Table 3). Incidences after 3 weeks of storage are shown. To control green mold on Fukimoto navel orange, decreasing the storage temperature from 20 to 15 to $10^{\circ} \mathrm{C}$ significantly ( $P$ $\leq 0.000)$ improved the control of green mold. Increasing the temperature of the $\mathrm{KP}$ solution from 25 to $50^{\circ} \mathrm{C}$ significantly $(P \leq$

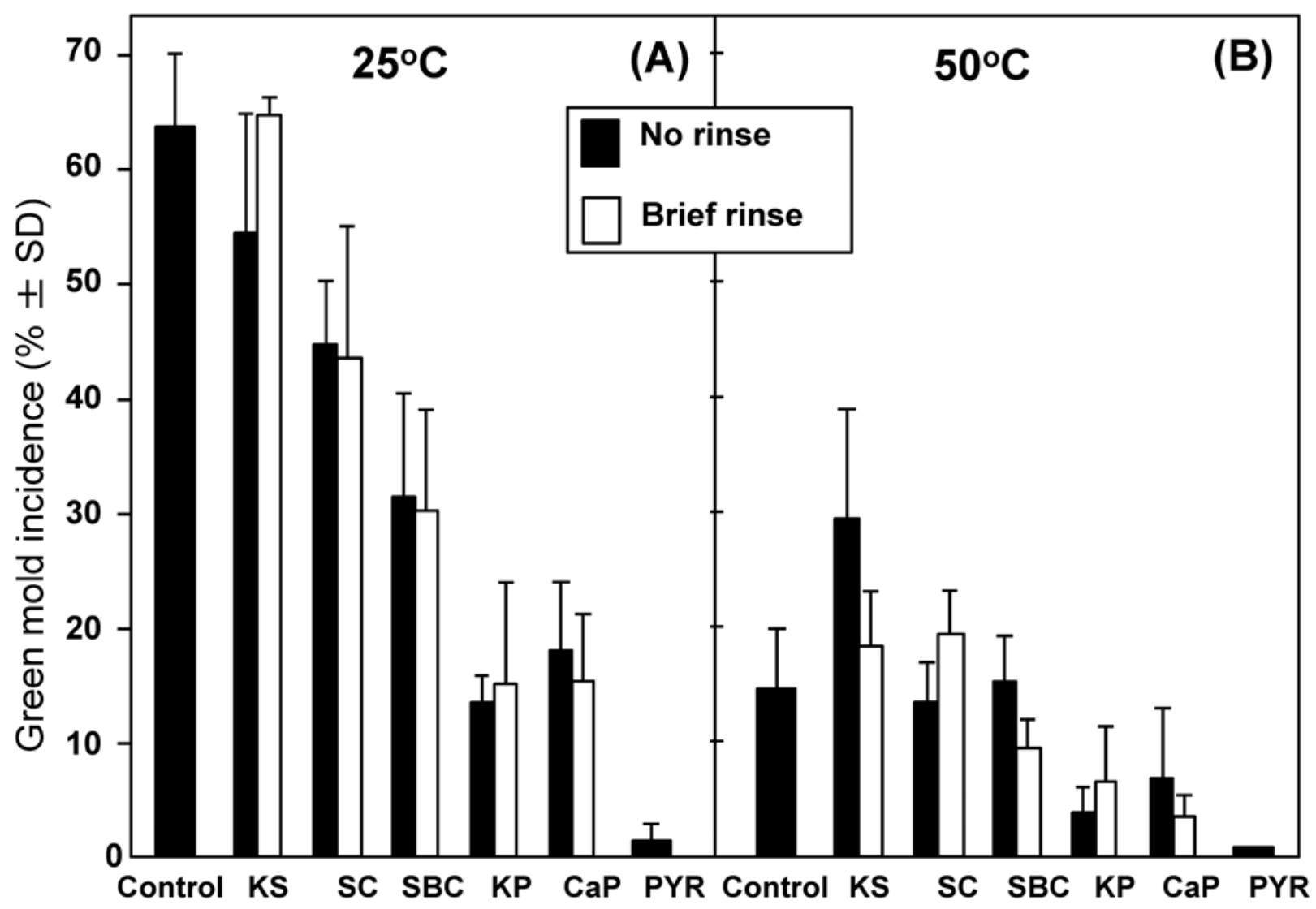

Fig. 2. Green mold incidence among 'WMurcott' mandarin orange fruit inoculated with Penicillium digitatum (imazalil-resistant isolate D201) and $24 \mathrm{~h}$ before they were immersed for $1 \mathrm{~min}$ in (i) water alone (Control); potassium sorbate (KS) at $20 \mathrm{~g} /$ liter; (iii) sodium carbonate (SC); (iv) sodium bicarbonate (SBC); (v) potassium phosphate (KP), (vi) calcium phosphite (CaP), or (vii) pyrimethanil (PYR) at 1 /liter. The temperature of the solutions was $\mathbf{A}, 25^{\circ} \mathrm{C}$ or $\mathbf{B}, 50^{\circ} \mathrm{C}$. All were stored 1 week at $20^{\circ} \mathrm{C}$ before the incidence of green mold was determined.

Table 2. Green mold incidence among 'Barnfield' orange after treatment with calcium phosphite or potassium phosphite at different temperatures

\begin{tabular}{|c|c|c|c|c|c|c|}
\hline \multirow[b]{3}{*}{ Treatment temperature $\left({ }^{\circ} \mathbf{C}\right)$} & \multicolumn{4}{|c|}{ Green mold incidence $(\%)^{\mathrm{z}}$} & \multirow[b]{3}{*}{$\mathbf{L S D}_{0.05}$} & \multirow[b]{3}{*}{$\boldsymbol{P}$} \\
\hline & \multicolumn{2}{|c|}{ Calcium phosphite (g/liter) } & \multicolumn{2}{|c|}{ Potassium phosphite (g/liter) } & & \\
\hline & 5 & 15 & 5 & 15 & & \\
\hline 21 & 22.5 & 5.0 & 18.3 & 10.0 & 4.98 & 0.017 \\
\hline 41 & 27.5 & 5.8 & 10.8 & 5.8 & 4.39 & 0.003 \\
\hline 46 & 32.5 & 10.0 & 16.7 & 11.7 & 6.28 & 0.015 \\
\hline 52 & 10.0 & 1.7 & 6.7 & 1.7 & 2.70 & 0.05 \\
\hline 57 & 13.3 & 4.2 & 6.7 & 0.8 & nsd & 0.06 \\
\hline $\mathrm{LSD}_{0.05}$ & 4.8 & nsd & nsd & nsd & $\ldots$ & $\ldots$ \\
\hline$P$ & 0.002 & 0.279 & 0.116 & 0.076 & $\ldots$ & $\ldots$ \\
\hline
\end{tabular}

${ }^{\mathrm{z}}$ Each fruit was inoculated twice with Penicillium digitatum (isolate D201) $24 \mathrm{~h}$ before they were immersed for $15 \mathrm{~s}$ in water at room temperature (untreated control) or phosphite salt solutions at 5 or $15 \mathrm{~g} /$ liter and $21,41,46,52$, or $57^{\circ} \mathrm{C}\left( \pm 0.5^{\circ} \mathrm{C}\right)$. Each treatment was applied to three replicates of 20 fruit each. Fruit were examined after storage for 2 weeks at $20^{\circ} \mathrm{C}$. Fisher's protected least significant difference (LSD) is shown for values within columns and rows; the untreated control is excluded; nsd = no significant difference. Incidence among untreated control fruit was $98.3 \%$. 
0.000) improved control of this disease (Table 3). Similarly, on Clementina de Nule mandarin orange, decreasing the storage temperature from 20 to 15 to $10^{\circ} \mathrm{C}(P \leq 0.000)$ or increasing the temperature of the $\mathrm{KP}$ solution from 25 to $50^{\circ} \mathrm{C}$ significantly $(P \leq$ $0.000)$ improved the control of green mold. Water alone at $50^{\circ} \mathrm{C}$ controlled green mold substantially on both Fukimoto fruit and Clementina de Nule fruit, particularly when the storage temperature after treatment was $10^{\circ} \mathrm{C}$.

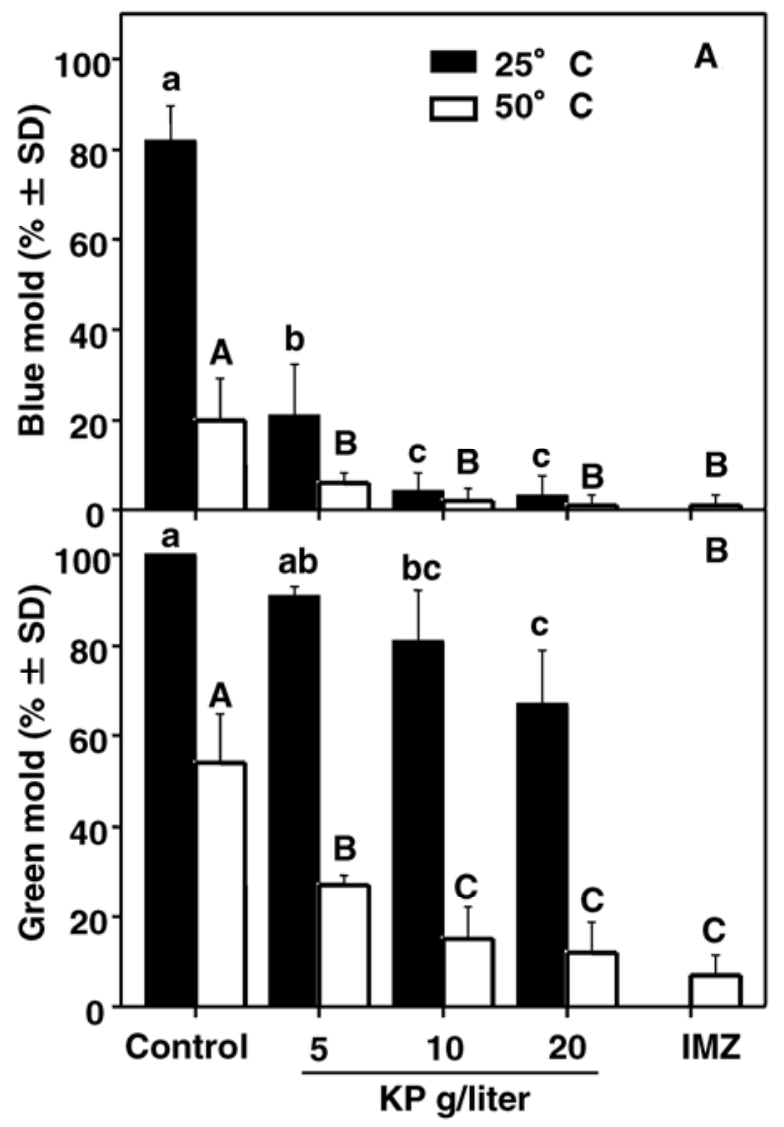

Fig. 3. A, Blue mold and B, green mold incidence among 'Eureka' lemon fruit inoculated with Penicillium digitatum (isolate PD90) or $P$. italicum $24 \mathrm{~h}$ before they were immersed for $1 \mathrm{~min}$ in water (control) or potassium phosphite (KP) at 5,10 , or $20 \mathrm{~g} /$ liter and 25 or $50^{\circ} \mathrm{C}$, or immersion for $15 \mathrm{~s}$ in imazalil (IMZ) at $0.2 \mathrm{~g} /$ liter and $50^{\circ} \mathrm{C}$ followed by storage for 2 weeks at $20^{\circ} \mathrm{C}$. Each treatment was applied to five replicates of 20 fruit each. Columns with the same letters (uppercase letters for $50^{\circ} \mathrm{C}$ and lowercase letters for $25^{\circ} \mathrm{C}$ ) are not significantly different according to Tukey's honestly significant difference $(P=0.05)$.
Increasing the temperature of the $\mathrm{KP}$ solution from 25 to $50^{\circ} \mathrm{C}$ significantly $(P \leq 0.000)$ improved control of blue mold on $\mathrm{Fu}-$ kimoto navel orange (Table 3 ). Decreasing the storage temperature from 20 or 15 to $10^{\circ} \mathrm{C}$ significantly $(P=0.012)$ improved the control of blue mold. Similarly, on Clementina de Nule mandarin orange, increasing the temperature of the KP solution from 25 to $50^{\circ} \mathrm{C}$ significantly $(P=0.007)$ improved the control of blue mold. However, in contrast to the results with green mold, decreasing the storage temperature did not significantly $(P=0.119)$ improve the control of blue mold on Clementina de Nule mandarin orange. Water alone at $50^{\circ} \mathrm{C}$ controlled blue mold substantially on $\mathrm{Fu}$ kimoto fruit but was not very effective on Clementina de Nule fruit.

Evaluation of KP combined with conventional postharvest fungicides to control green mold. Control of green mold on Eureka lemon by all the fungicides tested was significantly improved when KP at $4 \mathrm{~g} /$ liter was added to the tank solutions (Fig. 4). Decay incidence was high after KP treatment. The IMZ-resistant isolate of $P$. digitatum used in this test (D201) was controlled by IMZ at $0.5 \mathrm{~g} /$ liter. In a second experiment, this isolate was inadequately controlled on Eureka lemon by IMZ at $0.2 \mathrm{~g} /$ liter. SBC treatment alone reduced green mold incidence moderately but significantly at the two temperatures assayed and KP effectiveness alone was again poor. However, the combination of KP and IMZ or $\mathrm{KP}$ and SBC improved in effectiveness to control green mold in lemon when they were used at $40^{\circ} \mathrm{C}$ (Fig. 5). The combination of $\mathrm{KP}$ with SBC was particularly effective to control green mold in lemon, even when used at $20^{\circ} \mathrm{C}$.

In the large-scale test that employed commercial pack line equipment, results with the two isolates of $P$. digitatum were not significantly $(P=0.120)$ different; therefore, they were combined (Table 4). Control of green mold on Eureka lemon, WMurcott mandarin orange, and Atwood navel orange by $\mathrm{KP}$ alone at $46^{\circ} \mathrm{C}$ was insufficient for commercial purposes although significantly different of the control, whereas $\mathrm{CaP}$ alone or IMZ alone much more effective (Table 4).

Influence of the time of inoculation on KP and IMZ effectiveness. The combination of KP with IMZ was more effective than either IMZ or KP alone to prevent Eureka lemon or Valencia orange from developing green mold when inoculation with $P$. digitatum was made 5 days after treatment (Table 5). Protection from infection by treatments with either KP or IMZ alone was inadequate on Eureka lemon and Valencia orange. In a second experiment, both post-infection control and protection from blue mold were insufficient for fruit treated by KP. Blue mold incidence among Eureka lemon fruit inoculated $72 \mathrm{~h}$ or longer after KP treatment was similar to the control (Fig. 6A). Both eradication and protection from blue mold or green mold infections were excellent by IMZ alone or IMZ combined with KP (Fig. 6A and B). IMZ

Table 3. Green mold and blue mold incidence among 'Fukimoto' navel orange and 'Clementina de Nule' mandarin orange after treatment with potassium phosphite at 25 or $50^{\circ} \mathrm{C}$ followed by storage for 3 weeks at 10,15 , or $20^{\circ} \mathrm{C}$

\begin{tabular}{|c|c|c|c|c|c|c|c|}
\hline \multirow[b]{3}{*}{ Variety, treatment } & \multirow[b]{3}{*}{ Solution $\left({ }^{\circ} \mathbf{C}\right)$} & \multicolumn{6}{|c|}{ Storage temperature $\left({ }^{\circ} \mathrm{C}\right)^{\mathrm{z}}$} \\
\hline & & \multicolumn{3}{|c|}{ Green mold (\%) } & \multicolumn{3}{|c|}{ Blue mold (\%) } \\
\hline & & 10 & 15 & 20 & 10 & 15 & 20 \\
\hline \multicolumn{8}{|l|}{ Fukimoto } \\
\hline Water & 25 & $46.7 \mathrm{a}$ & $70.0 \mathrm{a}$ & $95.0 \mathrm{a}$ & $88.3 \mathrm{a}$ & $90.0 \mathrm{a}$ & $75.0 \mathrm{a}$ \\
\hline Potassium phosphite & 25 & $1.7 \mathrm{~b}$ & $16.7 \mathrm{~b}$ & $61.7 \mathrm{~b}$ & $25.0 \mathrm{~b}$ & $63.3 \mathrm{~b}$ & $70.0 \mathrm{a}$ \\
\hline Water & 50 & $0.0 \mathrm{~b}$ & $16.7 \mathrm{~b}$ & $24.4 \mathrm{c}$ & $26.7 \mathrm{~b}$ & $25.0 \mathrm{c}$ & $30.2 \mathrm{~b}$ \\
\hline Potassium phosphite & 50 & $0.0 \mathrm{~b}$ & $3.3 \mathrm{c}$ & $15.0 \mathrm{c}$ & $0.0 \mathrm{c}$ & $1.7 \mathrm{~d}$ & $6.7 \mathrm{c}$ \\
\hline \multicolumn{8}{|l|}{ Clementina de Nule } \\
\hline Water & 25 & $41.7 \mathrm{a}$ & $65.0 \mathrm{a}$ & $80.0 \mathrm{a}$ & $86.7 \mathrm{a}$ & $95.0 \mathrm{a}$ & $85.0 \mathrm{a}$ \\
\hline Potassium phosphite & 25 & $10.0 \mathrm{~b}$ & $21.7 \mathrm{~b}$ & $50.2 \mathrm{bc}$ & $28.3 \mathrm{c}$ & $66.7 \mathrm{~b}$ & $51.7 \mathrm{~b}$ \\
\hline Water & 50 & $6.7 \mathrm{~b}$ & $31.7 \mathrm{~b}$ & $64.8 \mathrm{~b}$ & $75.0 \mathrm{a}$ & $83.3 \mathrm{a}$ & $53.7 \mathrm{~b}$ \\
\hline Potassium phosphite & 50 & $0.0 \mathrm{c}$ & $8.3 \mathrm{c}$ & $42.2 \mathrm{c}$ & $43.3 \mathrm{~b}$ & $26.7 \mathrm{c}$ & $55.5 \mathrm{~b}$ \\
\hline
\end{tabular}

${ }^{\mathrm{z}}$ Fruit were inoculated with Penicillium digitatum (isolate PD90) or P. italicum (isolate PI105). After $24 \mathrm{~h}$ at $20^{\circ} \mathrm{C}$, they were immersed for 1 min in water or potassium phosphite $(20 \mathrm{~g} / \mathrm{liter})$ at 25 or $50^{\circ} \mathrm{C}$, then stored 3 weeks at 10,15 , or $20^{\circ} \mathrm{C}$. Each value is the mean of three replicates of 20 fruit each. Values within columns for each cultivar followed by the same letters are not significantly different according an analysis of variance applied to arcsin transformed values followed by Tukey's honestly significant difference $(P=0.05)$. Actual values are shown. 
alone controlled green mold infections from inoculations made 48 or $24 \mathrm{~h}$ before treatments and significantly improved when KP was added (Fig. 6B). The combination of KP with IMZ was more effective than either IMZ or KP alone to protect Eureka lemon inoculated $120 \mathrm{~h}$ after treatment with $P$. digitatum from developing green mold. $\mathrm{KP}$ at $5 \mathrm{~g} /$ liter alone at $25^{\circ} \mathrm{C}$ did not control green mold in this test.

Fungicide residues. Initial residues of phosphite in Atwood orange were not influenced by the temperature of the KP treatment or presence of IMZ or TBZ (Table 6). Phosphite content in untreated control fruit was low but measureable and declined during cold storage. After 21 days, residues of phosphite were unchanged, except those after the KP + IMZ treatment, which were significantly lower (Table 6). IMZ and TBZ residues when measured initially generally increased when the treatment temperature increased from 25 to $50^{\circ} \mathrm{C}$, although the increase was modest and often not significant. The addition of KP slightly but significantly increased IMZ residues when IMZ was applied at $50^{\circ} \mathrm{C}$ and approximately doubled TBZ residues when TBZ was applied at $25^{\circ} \mathrm{C}$. After 21 days of storage at $5^{\circ} \mathrm{C}$, the increase in IMZ residues associated with the heated $\mathrm{KP}+\mathrm{IMZ}$ treatment remained significant whereas the increase in TBZ residues did not.

Influence of postharvest treatments with KP on fruit surface color during ethylene degreening. The change in the rind color, expressed as hue angle (Fig. 7), was not influenced by KP treatment at either 25 or $50^{\circ} \mathrm{C}$ in ethylene. The change in hue angle in air was slightly but significantly delayed in WMurcott mandarin orange treated with water at $50^{\circ} \mathrm{C}$ and in Eureka lemon treated with water or $\mathrm{KP}$ at $50^{\circ} \mathrm{C}$.

\section{Discussion}

Fenn and Coffee (18) reported that phosphate influenced phosphite toxicity, and our results confirm that increased phosphate content decreases phosphite inhibition of $P$. digitatum. Using

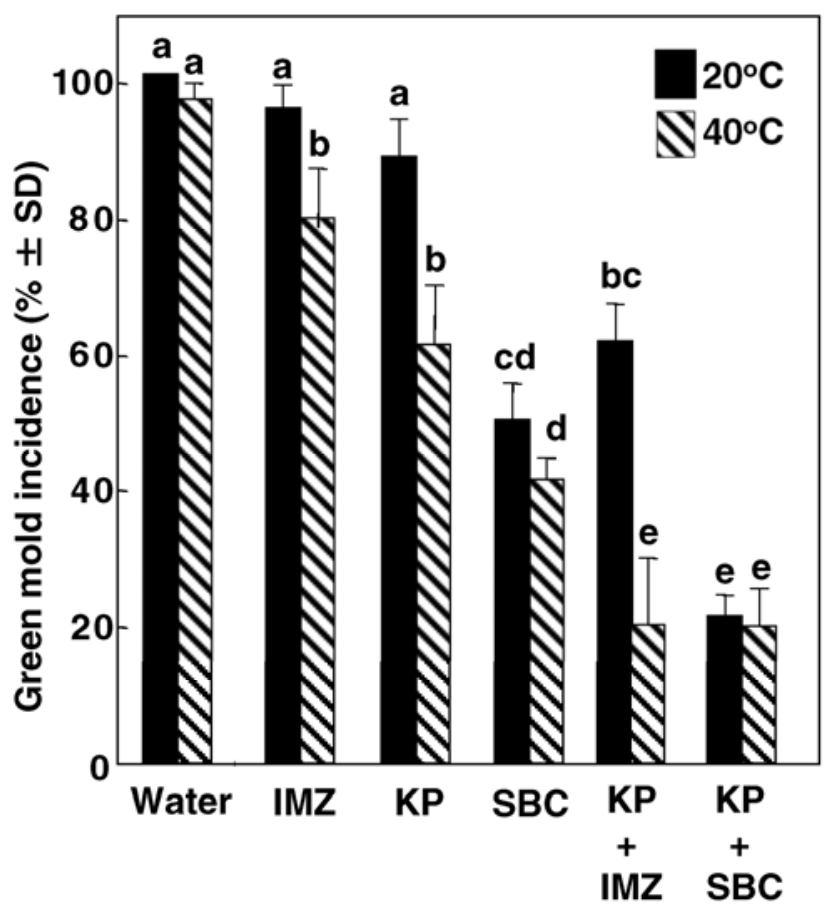

Fig. 5. Green mold incidence among 'Eureka' lemon fruit inoculated with Penicillium digitatum (isolate D201) $24 \mathrm{~h}$ before they were immersed for $2 \mathrm{~min}$ at 20 or $40^{\circ} \mathrm{C}$ $\left( \pm 0.5^{\circ} \mathrm{C}\right)$ in (i) imazalil (IMZ) at $0.2 \mathrm{~g} /$ liter, (ii) KP (formulation B) at $10 \mathrm{~g} /$ liter, (iii) sodium bicarbonate $(\mathrm{SBC})$ at $20 \mathrm{~g} /$ liter, (iv) a mixture of $\mathrm{KP}+\mathrm{IMZ}$, or (V) a mixture of $\mathrm{KP}+\mathrm{SBC}$. Fruit were not rinsed after treatment and stored for 21 days at $20^{\circ} \mathrm{C}$; then, the number of infected fruit was counted. Each treatment was applied to four replicates of 27 fruit each. Columns with the same letters are not significantly different according to Tukey's honestly significant difference $(P=0.05)$.

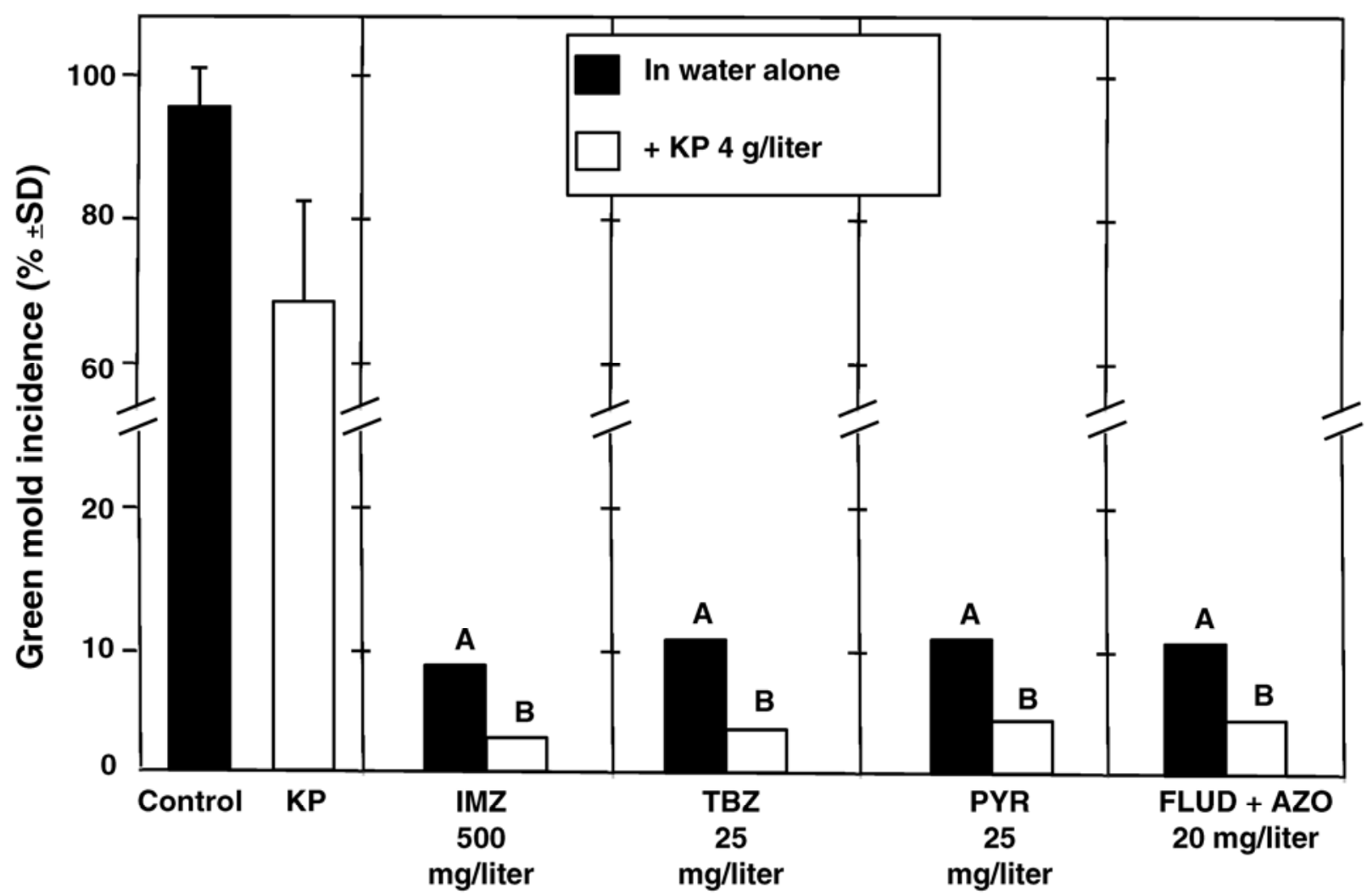

Fig. 4. Green mold incidence among 'Eureka' lemon fruit inoculated with Penicillium digitatum (isolate D201) $24 \mathrm{~h}$ before they were immersed for $30 \mathrm{~s}$ in $25^{\circ} \mathrm{C}$ solutions of (i) imazali (IMZ) at $0.5 \mathrm{~g} /$ liter, (ii) thiabendazole (TBZ) at $0.025 \mathrm{~g} /$ liter, (iii) pyrimethanil (PYR) at $0.025 \mathrm{~g} /$ liter, or (iv) a mixture of fludioxonil (FLUD) + azoxystrobin (AZO) that contained each at $0.020 \mathrm{~g} /$ liter. They were applied alone or dissolved in potassium phosphite (KP) at $4 \mathrm{~g} /$ liter. Fruit were not rinsed after treatment and were stored for 17 days at $10^{\circ} \mathrm{C}$ and $95 \%$ relative humidity; then, the number of decayed fruit was counted. Each treatment was applied to four replicates of 27 lemon fruit each. Columns with the same letters are not significantly different according to Tukey's honestly significant difference $(P=0.05)$. 
Pratt's medium (53) at $\mathrm{pH} 6$ with phosphate in excess $(10 \mathrm{mM})$, $\mathrm{EC}_{50}$ concentrations of $\mathrm{H}_{3} \mathrm{PO}_{3}$ that inhibited conidial germination were $469 \mathrm{mg} / \mathrm{liter}$, which was similar to the phosphite concentration of $552 \mathrm{mg} / \mathrm{liter}$ reported by Fenn and Coffey (18) that reduced radial growth rate of Alternaria alternata by $59 \%$ and of Rhizoctonia solani by $38 \%$ on cornmeal agar at $\mathrm{pH} 6.2$, a medium rich in phosphate. However, in a synthetic medium with a low phosphate concentration $(0.084 \mathrm{mM}), \mathrm{EC}_{50}$ concentrations of $\mathrm{H}_{3} \mathrm{PO}_{3}$ at $\mathrm{pH} 6.2$ that inhibited radial growth of Rhizopus stolonifer, Fusarium oxysporum, and Verticillium dahlia were only 69 $\mathrm{mg} / \mathrm{liter}$, and the toxicity of phosphite to these fungi declined markedly as the phosphate content increased.

The $\mathrm{pH}$ of phosphite solutions influenced inhibition of conidial germination of $P$. digitatum. Phosphite was approximately twice as inhibitory to conidial germination at $\mathrm{pH} 3$ as it was at $\mathrm{pH} 7$. This is the first report that quantifies the influence of $\mathrm{pH}$ on phosphite toxicity in vitro. In preliminary tests using inoculated fruit, the effectiveness of $\mathrm{KP}$ solutions ( $2 \% \mathrm{wt} / \mathrm{vol})$ adjusted to intervals of one $\mathrm{pH}$ unit from $\mathrm{pH} 3$ to 8 to control green mold was similar and was not significantly influenced by solution $\mathrm{pH}$ (data not shown). It is likely that the $\mathrm{pH}$ of the albedo tissue in the rind wounds was not altered much by the $\mathrm{pH}$ of the phosphite solutions. In prior work, the $\mathrm{pH}$ of this tissue in lemon wounds $1 \mathrm{~mm}$ wide and $2 \mathrm{~mm}$ deep in size was measured with a 0.5 -mm-diameter $\mathrm{pH}$ electrode at a depth of $1.5 \mathrm{~mm}$ after various treatments (46). The $\mathrm{pH}$ of albedo tissue was well buffered and resisted alteration; immersion of the fruit in high-pH bicarbonate solutions raised the $\mathrm{pH}$ of the rind tissue within the wounds approximately one unit and it returned to its natural $\mathrm{pH}$ (5.1 to 5.6) within 1 day (46).

Reports describing the postharvest use of phosphites to control diseases caused by true fungi are few. Gutter (25) reported that the phosphite-generating compound fosetyl-Al had modest activity on the control of postharvest green mold on orange at concentrations that effectively controlled brown rot. Furthermore, fosetyl-Al in vitro moderately inhibited the growth and sporulation of $P$. digitatum at 5, 10, or $20 \mathrm{~g} /$ liter but it was less effective when TBZresistant isolates were examined. More recently, Bassay Blum et al. (7) reported that immersion of apple fruit in KP and CaP solutions controlled blue mold caused by $P$. expansum. Amiri and Bompeix (5) reported that KP inhibited conidial germination and mycelia growth of $P$. expansum in vitro and it was more effective when applied in heated solutions. Treatment with KP at $20 \mathrm{~g} /$ liter and $50^{\circ} \mathrm{C}$ for 3 min completely suppressed blue mold in Elstar apple fruit after 7 days of storage at $20^{\circ} \mathrm{C}$. Reuveni et al. (40) reported that postharvest treatment of apple fruit with $\mathrm{KP}$ at $0.5 \mathrm{~g} / \mathrm{liter}$ controlled moldy-core decay of apple fruit, even when applied $48 \mathrm{~h}$ after inoculation with $A$. alternata.

$\mathrm{KP}$ and $\mathrm{CaP}$ at 10 or $20 \mathrm{~g} /$ liter were similar in effectiveness. If $\mathrm{CaP}$ was used under commercial conditions, a post-treatment rinse would be needed to eliminate the visible $\mathrm{CaP}$ residues. Unfortunately, if $\mathrm{CaP}$ was used with a fungicide, rinsing to remove visible $\mathrm{CaP}$ residue would also remove some portion of the fungicide residue. For $\mathrm{CaP}$ to be used with a fungicide, fruit would be treated with $\mathrm{CaP}$ first, then rinsed and partially dried before the fungicide would be applied. The effectiveness of this approach needs evaluation before it could be recommended. In the present work, phosphite treatments remained effective even with post-treatment water rinsing of the treated fruit (Fig. 2). In prior work with SBC, inoculated fruit were treated and the effectiveness of the treatment was little reduced by subsequent rinsing, unless it was very thorough (49).

The influence of post-treatment storage temperature on KP effectiveness for the control of green mold was large; storage at $20^{\circ} \mathrm{C}$ particularly reduced $\mathrm{KP}$ effectiveness compared with storage at 10 or $15^{\circ} \mathrm{C}$. KP adequately controlled blue mold on Fukimoto navel orange but not Clementina de Nule mandarin orange, even when the $\mathrm{KP}$ solution was heated to $50^{\circ} \mathrm{C}$ and the storage temperature was low $\left(10^{\circ} \mathrm{C}\right)$. In general, using the coldest feasible storage temperature is important to minimize green mold, whereas reducing storage temperature has less effect on blue mold (38). The effect of post-treatment storage temperature on the effectiveness of the KP treatments was very large and could, in part, explain the irregular effectiveness of $\mathrm{KP}$ reported to us by some industry personnel.

$\mathrm{KP}$ was compatible with all of the fungicides currently registered for postharvest use in the United States, and improved their performance. In work not reported here, we found that the combination of low-pH formulations of KP with IMZ was less effective than IMZ alone. When this occurred, IMZ residues were markedly lower when it was used with KP, which was likely a consequence of the effect of low $\mathrm{pH}$ reducing both residues (17) and potency (46) of IMZ. The improvement in IMZ performance we observed when adding phosphite was possibly related to an increase in IMZ residues in the fruit, because the addition of $\mathrm{KP}$ increased IMZ residues when treatment solutions were $50^{\circ} \mathrm{C}$. The addition of KP increased TBZ residues in orange when treatments were applied at $25^{\circ} \mathrm{C}$, and this difference could explain the improved effectiveness of this combination in comparison with the fungicide applied alone. The magnitude of this difference in residues was not evident after 3 weeks of storage at $5^{\circ} \mathrm{C}$. The residues of both fungicides were increased when they were applied at $50^{\circ} \mathrm{C}$, which has been reported previously for all the fungicides used in our work (44). SBC, which also markedly improved IMZ performance, was shown by Dore et al. (13) to cause a

Table 5. Green mold incidence among 'Eureka' lemon or 'Valencia' orange inoculated 5 days after immersion for $30 \mathrm{~s}$ at $25^{\circ} \mathrm{C}$ in imazalil (IMZ) at 0.5 $\mathrm{g} /$ liter, potassium phosphite at $50 \mathrm{~g} /$ liter, or a mixture of both, followed by storage for 1 week at $20^{\circ} \mathrm{C}$

\begin{tabular}{lcc}
\hline & \multicolumn{2}{c}{ Green mold incidence $(\%)^{\mathbf{z}}$} \\
\cline { 2 - 3 } Treatment & Lemon & Orange \\
\hline Control & $100.0 \mathrm{a}$ & $78.8 \mathrm{a}$ \\
IMZ & $100.0 \mathrm{a}$ & $45.0 \mathrm{~b}$ \\
Potassium phosphite & $99.1 \mathrm{a}$ & $37.5 \mathrm{~b}$ \\
IMZ + potassium phosphite & $2.8 \mathrm{~b}$ & $18.8 \mathrm{c}$ \\
\hline
\end{tabular}

${ }^{z}$ After 5 days at $10^{\circ} \mathrm{C}$, the lemon fruit were all inoculated with IMZresistant Penicillium digitatum (isolate D201). Values within columns followed by the same letters are not significantly different according an analysis of variance applied to arcsin-transformed values followed by Tukey's honestly significant difference $(P=0.05)$. Actual values are shown.

Table 4. Green mold incidence among 'Atwood' orange, 'Eureka' lemon, or 'WMurcott' mandarin orange after treatments with calcium phosphite (formulation C) at $15 \mathrm{~g} /$ liter, potassium phosphite (formulation B) at $15 \mathrm{~g} /$ liter, or imazalil (IMZ) after storage for 3 weeks at $20^{\circ} \mathrm{C}$

\begin{tabular}{lcccc}
\hline & \multicolumn{4}{c}{ Green mold incidence (\%) on fruit variety } \\
\cline { 2 - 5 } Treatment & Orange & Lemon & Mandarin orange & All \\
\hline Control & $92.9 \mathrm{a}$ & $97.3 \mathrm{a}$ & $85.1 \mathrm{a}$ & $91.7 \mathrm{a}$ \\
Potassium phosphite & $20.2 \mathrm{~b}$ & $47.0 \mathrm{~b}$ & $40.7 \mathrm{~b}$ & $36.7 \mathrm{~b}$ \\
Calcium phosphite & $4.6 \mathrm{c}$ & $10.2 \mathrm{c}$ & $20.8 \mathrm{c}$ & $12.1 \mathrm{c}$ \\
IMZ & $0.0 \mathrm{~d}$ & $0.5 \mathrm{~d}$ & $4.1 \mathrm{~d}$ & $1.7 \mathrm{~d}$ \\
\hline
\end{tabular}

${ }^{\mathrm{z}}$ Fruit were inoculated with Penicillium digitatum (isolate PD90 or D201) $24 \mathrm{~h}$ before treatments and were treated by passage down a packing line, where they were drenched for $15 \mathrm{~s}$. The IMZ concentration was 50 or $500 \mathrm{mg} /$ liter for isolates PD 90 or D201, respectively. The solution temperature was $46^{\circ} \mathrm{C}$. Values within columns followed by the same letters are not significantly different according an analysis of variance applied to arcsin-transformed values followed by Tukey's honestly significant difference $(P=0.05)$. Actual values are shown. 
displacement of intracuticular waxes that affected IMZ sorption, thereby allowing deeper diffusion into the rind, particularly into the albedo in rind wounds. It is conceivable that KP also alters the rind tissue and the distribution of the residues of these fungicides.

Residues of phosphite in orange peel were stable and not influenced by treatment temperature or the presence of IMZ or TBZ. However, after storage for 3 weeks, phosphite levels declined significantly in orange after IMZ + KP treatment. This may have occurred for several reasons. The phosphite residue may have reacted with IMZ so that less phosphite was present, although this seems unlikely because IMZ residues were not lower among orange fruit in which the phosphite content had declined. It is possible that the phosphite residue had diffused deeper into the rind and that this was caused by some aspect of the IMZ treatment, such as the surfactants in the IMZ formulation. The decline in phosphite residues associated with the KP + IMZ treatment may have a practical consequence. The phosphite-induced resistance of fruit to Phytophthora spp. $(3,43,52)$ may be less persistent than when KP is used alone. Further investigation of the interactions, distribution, and persistence of these residues is needed.

Although not evaluated in this work, phosphites have long been known to control fruit rot caused by Phytophthora brown rot $(10,19,20)$, a disease that caused significant losses in wet years in California. Adaskaveg (2) reported a brief immersion of orange fruit in $\mathrm{KP}$ at $0.27 \mathrm{~g} /$ liter had excellent preinfection and postinfection control of Phytophthora citrophthora, and it was the only fungicide of many tested with postinfection activity in that study. Thus, the phosphite treatments that controlled green mold and blue mold would be expected to control brown rot, because the phosphite rates that controlled them were far higher than those that

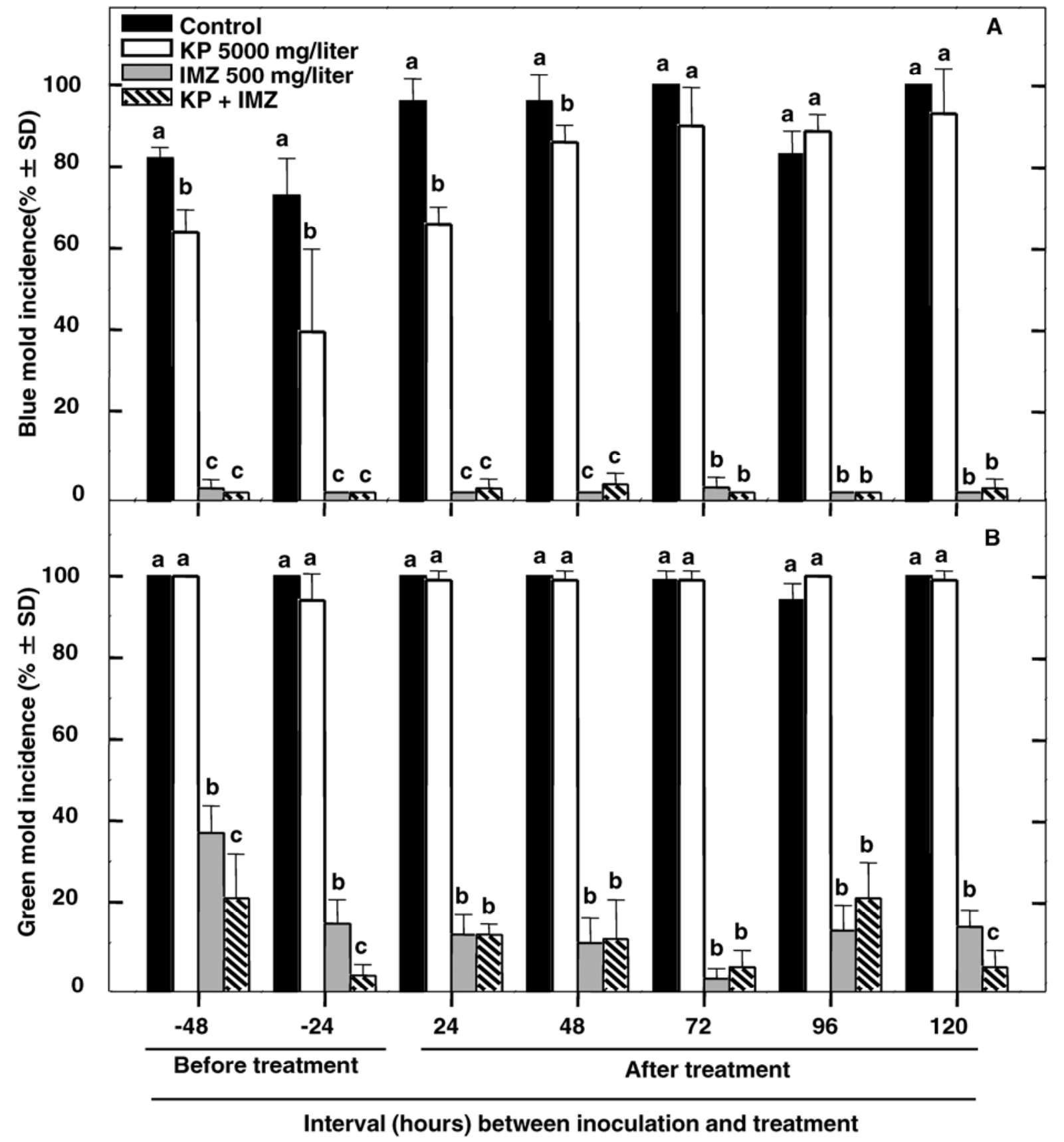

Fig. 6. Protectant and eradicant activity of potassium phosphite (KP) and imazalil (IMZ) treatments to control A, blue mold and B, green mold on 'Eureka' lemon. The interval between inoculation with Penicillium digitatum (isolate PD90) or $P$. italicum and treatment was varied; from inoculation $48 \mathrm{~h}$ before treatment $(-48)$ to inoculation $120 \mathrm{~h}$ after treatment (120). Lemon fruit were immersed for $30 \mathrm{~s}$ at $25^{\circ} \mathrm{C}$ in (i) water alone (control), (ii) IMZ at $0.5 \mathrm{~g} /$ /iter, (iii) $\mathrm{KP}$ at $5 \mathrm{~g} /$ liter, or (iv) a mixture of IMZ + KP. Fruit were not rinsed after treatment and were stored for 14 days at $20^{\circ} \mathrm{C}$; then, the number of infected fruit was counted. Each treatment was applied to five replicates of 20 lemon fruit each. Columns with the same letters are not significantly different within in each time according to Tukey's honestly significant difference $(P=0.05)$. 
Table 6. Residues of phosphite, imazalil (IMZ), or thiabendazole (TBZ) in the rind of 'Atwood' orange after $30 \mathrm{~s}$ of immersion in IMZ (0.4 g/liter) or thiabendazole TBZ ( $0.4 \mathrm{~g} /$ liter $)$ alone or in combination with potassium phosphite $(\mathrm{KP} ; 20 \mathrm{~g} / \mathrm{liter})$ at 25 or $50^{\circ} \mathrm{C}^{\mathrm{w}}$

\begin{tabular}{|c|c|c|c|c|c|c|c|}
\hline \multirow[b]{2}{*}{$\operatorname{Temp}\left({ }^{\circ} \mathbf{C}\right)^{\mathbf{y}}$} & \multirow[b]{2}{*}{ Storage (days) ${ }^{\mathrm{z}}$} & \multicolumn{6}{|c|}{ Residues $(\mathrm{mg} / \mathrm{kg} \text { fresh weight } \pm \mathrm{SD})^{\mathrm{x}}$} \\
\hline & & Treatment & Phosphite & Treatment & IMZ & Treatment & TBZ \\
\hline 25 & 2 & Control & $28 \pm 8 \mathrm{a}$ & Control & $0.09 \pm 0.04 \mathrm{a}$ & Control & $0.08 \pm 0.06 \mathrm{a}$ \\
\hline 25 & 21 & $\ldots$ & $6 \pm 4 b$ & $\ldots$ & $0.09 \pm 0.03 \mathrm{a}$ & $\ldots$ & $0.07 \pm 0.02 \mathrm{a}$ \\
\hline 50 & 2 & $\ldots$ & $36 \pm 12 \mathrm{a}$ & $\ldots$ & $0.10 \pm 0.06 \mathrm{a}$ & $\ldots$ & $0.08 \pm 0.04 \mathrm{a}$ \\
\hline 50 & 21 & $\ldots$ & $9 \pm 4 b$ & $\ldots$ & $0.10 \pm 0.05 \mathrm{a}$ & $\ldots$ & $0.04 \pm 0.03 \mathrm{a}$ \\
\hline 25 & 2 & $\mathrm{KP}$ alone & $318 \pm 86 \mathrm{de}$ & IMZ alone & $0.47 \pm 0.12 b$ & TBZ alone & $1.35 \pm 0.21 \mathrm{~b}$ \\
\hline 25 & 21 & $\ldots$ & $298 \pm 93 \mathrm{de}$ & $\ldots$ & $0.51 \pm 0.20 b$ & $\ldots$ & $1.88 \pm 0.83 \mathrm{bc}$ \\
\hline 50 & 2 & $\ldots$ & $319 \pm 67 \mathrm{de}$ & $\ldots$ & $0.69 \pm 0.10 \mathrm{c}$ & $\ldots$ & $2.55 \pm 0.56 \mathrm{c}$ \\
\hline 50 & 21 & $\ldots$ & $351 \pm 57 \mathrm{de}$ & $\ldots$ & $0.60 \pm 0.29 b c$ & $\ldots$ & $2.38 \pm 0.65 \mathrm{c}$ \\
\hline 25 & 2 & $\mathrm{KP}+\mathrm{IMZ}$ & $291 \pm 75 \mathrm{de}$ & KP+IMZ & $0.49 \pm 0.17 \mathrm{~b}$ & $\ldots$ & nd \\
\hline 25 & 21 & $\ldots$ & $173 \pm 22 \mathrm{~cd}$ & $\ldots$ & $0.58 \pm 0.13 b c$ & $\ldots$ & nd \\
\hline 50 & 2 & $\ldots$ & $357 \pm 98 \mathrm{de}$ & $\ldots$ & $0.91 \pm 0.15 \mathrm{~d}$ & $\ldots$ & nd \\
\hline 50 & 21 & $\ldots$ & $117 \pm 29 \mathrm{c}$ & $\ldots$ & $1.26 \pm 0.19 \mathrm{~d}$ & $\ldots$ & nd \\
\hline 25 & 2 & KP+TBZ & $378 \pm 21 \mathrm{de}$ & $\ldots$ & nd & KP+TBZ & $2.79 \pm 0.48 c$ \\
\hline 25 & 21 & $\ldots$ & $357 \pm 95 \mathrm{e}$ & $\ldots$ & nd & $\ldots$ & $1.88 \pm 0.38 b c$ \\
\hline 50 & 2 & $\ldots$ & $259 \pm 56 \mathrm{de}$ & $\ldots$ & nd & $\ldots$ & $2.18 \pm 0.10 b c$ \\
\hline 50 & 21 & $\ldots$ & $259 \pm 47 \mathrm{de}$ & $\ldots$ & nd & $\ldots$ & $3.07 \pm 0.64 \mathrm{c}$ \\
\hline
\end{tabular}

${ }^{\mathrm{w}}$ Residues were determined within 2 days and again after storage $5^{\circ} \mathrm{C}$ for 21 days.

${ }^{x}$ Values were $\log _{10}$ transformed before analysis; those within columns followed by the same letters are not significantly different according to Fisher's Protected least significant difference $(P=0.05)$. $\mathrm{SD}=$ standard deviation. Actual values are shown; $\mathrm{nd}=$ not determined.

${ }^{\mathrm{y}}$ Treatment temperature of the solution in which the fruit were immersed.

${ }^{\mathrm{z}}$ Storage period at $5^{\circ} \mathrm{C}$

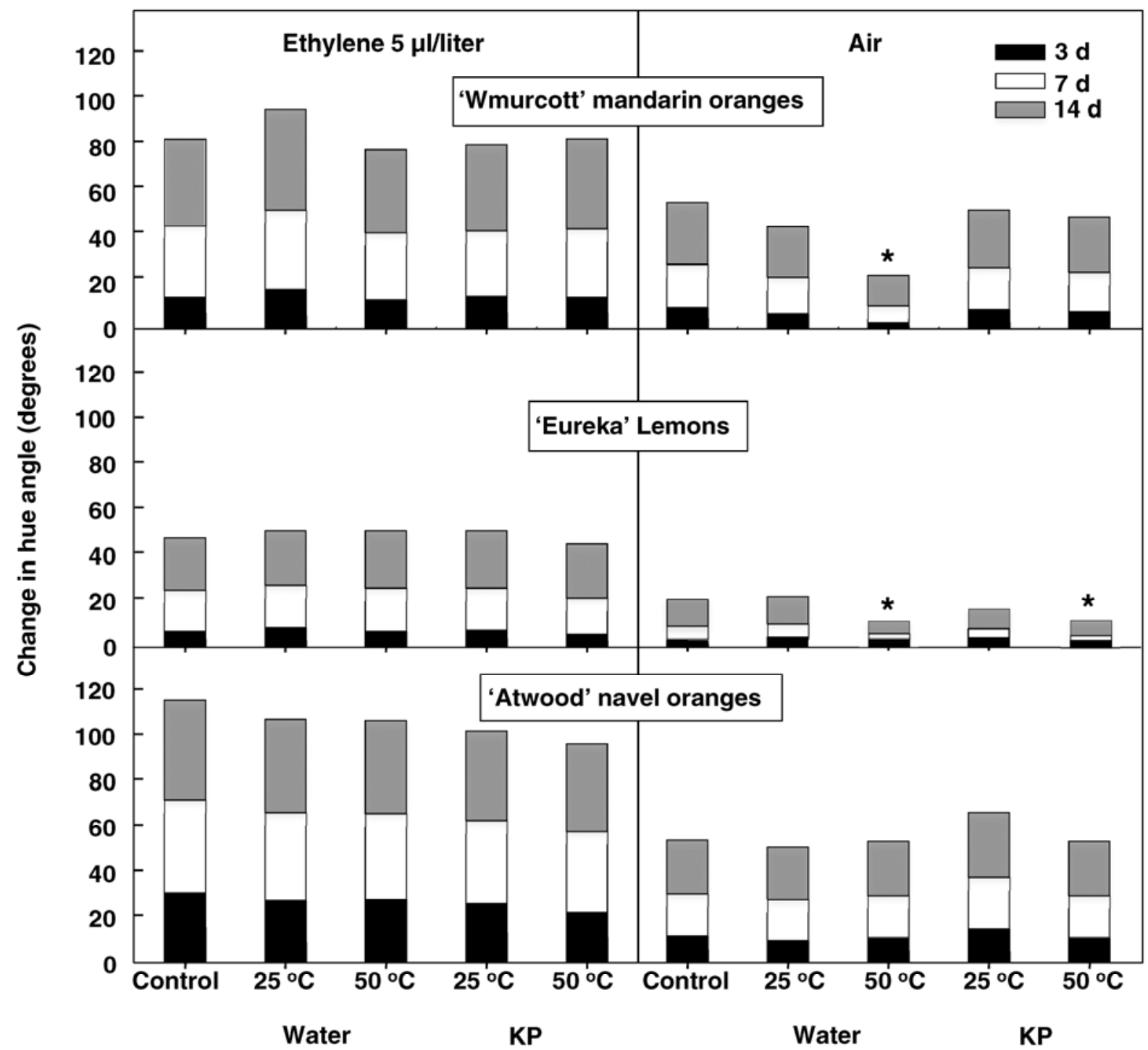

Fig. 7. Change in the surface color of the rind of 'Atwood' navel orange, 'WMurcott' mandarin orange, and 'Eureka' lemon fruit after immersion for $30 \mathrm{~s}$ in water or potassium phosphite (KP) at 25 or $50^{\circ} \mathrm{C}$ followed by continuous storage at $20^{\circ} \mathrm{C}$ in air or ethylene gas at $5 \mu / /$ liter. Asterisks indicate a significant difference from the control according to Tukey's honestly significant difference $(P=0.05)$. 
control brown rot (2). Furthermore, brown rot is readily controlled by immersion in heated water (29) using thermal regimes similar to those we employed to improve the phosphite effectiveness.

In conclusion, the effectiveness of phosphite salts for controlling citrus green and blue molds in laboratory and semicommercial tests was demonstrated on mandarin orange, lemon, and orange. Control of decay on Clementina de Nule mandarin orange was more difficult than other citrus fruit, in agreement with Palou et al. (37), who reported that treatments of hot water, SBC, and sodium carbonate were less effective on this cultivar than on other citrus fruit. Phosphites improved fungicide performance when added to other labeled fungicides, particularly in heated solutions. As a general rule, as temperature of the treatment increased the decay incidence decreased. In particular, a heated phosphite + IMZ treatment effectively controlled IMZ-resistant isolates of Penicillium digitatum, which are common within packinghouses (28). The effectiveness of phosphite treatment was greater when post-treatment fruit storage temperatures were lower. Although generally more effective for the control of green mold than other fungicide alternatives used in packinghouses such as carbonates, bicarbonates, or sorbates, the most compelling advantage of phosphites is their ability to control Phytophthora brown rot. Phosphites are more costly than these alternatives but were compatible with SBC, and a phosphite-SBC mixture could be used to reduce costs. Moreover, the combination of KP with SBC was an effective treatment to control green mold in lemon, even when used at $20^{\circ} \mathrm{C}$. Phosphite residues were persistent, and phosphite treatments did not influence rind color development in air or ethylene atmospheres and caused no visible rind injuries in any test.

\section{Acknowledgments}

We thank Consejo Nacional de Investigaciones Científicas yTécnicas and the California Citrus Research Board (project 5400-106) for financial support; K. Schmidt, D. Sorenson, G. Verduzco, and N. M. Grech for useful ideas, advice, and technical assistance; and D. Margosan for technical assistance and a thorough review of the manuscript.

\section{Literature Cited}

1. Adams F., and Conrad, J. P. 1953. Transition of phosphite to phosphate in soils. Soil Sci. 75:361-371.

2. Adaskaveg, J. E. 2009. Management of Citrus Brown Rot. http:// www.calcitrusquality.org/wp-content/uploads/2009/05/Citrus-Brown-RotJA-9-29-11.pdf

3. Afek, U., and Sztejnberg, A. 1989. Effects of Fosetyl-Al and phosphorous acid on scoparone, a phytoalexin associated with resistance of citrus to Phytophthora citrophthora. Phytopathology 79:736-739.

4. Albrigo, L. G. 1999. Effects of foliar applications of urea or nutriphite on flowering and yields of Valencia orange trees. Proc. Fla. State Hortic. Soc. 112:1-4.

5. Amiri, A., and Bompeix, G. 2011. Control of Penicillium expansum with potassium phosphite and heat treatment. Crop Prot. 30:222-227.

6. Barger, W. R. 1928. Sodium bicarbonate as citrus fruit disinfectant. Calif. Citrogr. 13:164:172-174

7. Bassay Blum, L. E., Vidal Tamarini do Amarante, C., Dezanet, A., Barreto de Lima, E., Hack Neto, P., Duarte Avila, R., and Siega, V. 2007. Fosfitos aplicados empós-colheita reduzem o mofo-azul em maçãs 'Fuji' e 'Gala'. Rev. Bras. Frutic. 2:265-268

8. Chalutz, E., Mattoo, A. K., Anderson, J. D., and Lieberman, M. 1978. Regulation of ethylene production by phosphate in Penicillium digitatum. Plant Cell Physiol. 19:189-196.

9. Coffey, M. D., and Joseph, M. C. 1985. Effects of phosphorous acid and fosetyl-Al on the life cycle of Phytophthora cinnamomi and P. citricola. Phytopathology 75:1042-1046.

10. Cohen, Y., and Coffey, M. D. 1986. Systemic fungicides and the control of Oomycetes. Annu. Rev. Phytopathol. 24:311- 338.

11. Cohen, E., Shalom, Y., Axelrod, Y., Adato, I., and Rosenberger, I.1987. Control and prevention of contact infection of brown rot disease with fosetyl-aluminum, and residue levels in post-harvest-treated citrus fruit. Pestic. Sci. 20:83-91.

12. Dercks, W., and Buchenauer, H. 1987. Comparative studies on the mode of action of aluminum ethyl phosphite in four Phytophthora species. Crop Prot. 6:82-89.

13. Dore, A., Molinu, M. G., Venditti, T., and D'hallewin, G. 2010. Sodium bicarbonate induces crystalline wax generation, activates host-resistance, and increases imazalil level in rind wounds of oranges, improving the control of green mold during storage. J. Agric. Food Chem. 58:7297-7304.
14. Dunhill, R. H. 1990. The manufacture and properties of phosphonic (phosphorous) acid. Aust. Plant Pathol. 19:138-139.

15. Eckert, J. W., and Brown, G. E. 1986. Evaluation of postharvest treatments for citrus fruits. Pages 92-97 in: Methods for Evaluating Pesticides for Control of Plan Pathogens. K. D. Hickey, ed. American Phytopathological Society, St. Paul, MN.

16. Eckert, J. W., and Eaks, I. L. 1989. Postharvest disorders and diseases of citrus fruits. Pages 179-260 in: The Citrus Industry, vol. V. W. Reuther, E. Calavan, and G. E. Carman, eds. University of California Press, Riverside.

17. Erasmus, A., Lennox, C. L., Jordaan, H., Smilanick, J. L., Lesar, K., and Fourie, P. H. 2011. Imazalil residue loading and green mould control in citrus packhouses. Postharvest Biol. Technol. 62:193-203.

18. Fenn, M. E., and Coffey, M. D. 1984. Studies on the in vitro and in vivo antifungal activity of fosetyl-Al and phosphorous acid. Phytopathology 74:606-611.

19. Gaulliard, J. M., and Pelossier, R. 1983. Efficacite de phosethyl Al en trempage des agrumes (fruits) contre Phytophthora parasitica agent de la pourriture bruneet contre Penicillium digitatum. Fruits 38:693-697.

20. Graham, J. H., and Timmer, L. W. 2011. Florida citrus pest management guide: brown rot of fruit. Fla. Coop. Ext. Serv. Doc. PP-148.

21. Griffin, D. H. 1981. Fungal Physiology. Wiley-Interscience, John Wiley and Sons, New York.

22. Guest, D. I. 1984. Modification of defense response in tobacco and capsicum following treatment with Fosetyl-Al [aluminum Tris (o-ethyl phosphonate)]. Physiol. Mol. Plant Pathol. 19:113-115.

23. Guest, D. I., and Bompeix, G. 1990. The complex mode of action of phosphonates. Aust. Plant Pathol. 19:113-115.

24. Guest, D. I., and Grant, B. R. 1991. The complex action of phosphonates as antifungal agents. Biol. Rev. 66:159-187.

25. Gutter, Y. 1983. Supplementary antimold activity of phosethyl Al, a new brown rot fungicide for citrus fruits. Phytopathol. Z. 107:301-308.

26. Holmes, G.J., and Eckert, J.W. 1999. Sensitivity of Penicillium digitatum and $P$. italicum to postharvest citrus fungicides in California. Phytopathology 89:716-721.

27. Ismail, M., and Zhang, J. 2004. Post-harvest citrus diseases and their control. Outlook Pest Manage. 15:29-35.

28. Kinay, P., Mansour, M. F., Gabler, F. M., Margosan, D. A., and Smilanick, J. L. 2007. Characterization of fungicide-resistant isolates of Penicillium digitatum collected in California. Crop Prot. 26:647-656.

29. Klotz, L. J., and DeWolfe, T. A. 1961. Brown rot contact infection of citrus fruits prior to hot water treatment. Plant Dis. Rep. 45:268-271.

30. Landschoot, P., and Cook, J. 2005. Understanding the phosphonates products. Department of Crop and Soil Sciences, The Pennsylvania State University, University Park, PA. Online publication. http://cropsoil.psu.edu/ turf/extension/factsheets/phosphonate-products

31. Leymonie, J. P. 2007. Phosphites and phosphates: when distributors and growers alike could get confused! New AgInt. 9:36-42.

32. Lovatt, C. J., and Mikkelsen, R. L. 2006. Phosphite fertilizers: what are they? Can you use them? What can they do? Better Crops 90:11-13.

33. Martin, H., Grant, B. R., and Stehmann, C. 1998. Inhibition of inorganic pyrophosphatase by phosphonate. A site of action on Phytophthora spp.? Pestic. Biochem. Physiol. 61:65-77.

34. McDonald, A. E., Grant, B., and Plaxton, W. C. 2001. Phosphite (phosphorous acid): Its relevance in the environment and agriculture and influence on plant phosphate starvation response. J. Plant Nutr.24:1505-1519.

35. McGuire, R. G. 1992. Reporting of objective color measurements. HortScience 27:1254-1255.

36. Palou, L., Smilanick, J. L., Usall, J., and Viñas, I. 2001. Control of postharvest blue and green molds of oranges by hot water, sodium carbonate, and sodium bicarbonate. Plant Dis. 85:371-376.

37. Palou, L., Usall, J., and Smilanick, J. L. 2002. Hot water, sodium carbonate and sodium bicarbonate for the control of blue and green molds of Clementine mandarins. Postharvest Biol. Technol. 24:93-96.

38. Plaza, P., Usall, J., Torres, R., Abadias, M., Smilanick, J. L., and Viñas, I 2002. The use of sodium carbonate to improve curing treatments against green and blue moulds on citrus fruits. Pest Manage. Sci. 60:815-821.

39. Porat, R., Daus, A., Weiss, B., Cohen, L., and Droby, S. 2002. Effects of combining hot water, sodium bicarbonate and biocontrol on postharvest decay of citrus fruit. J. Hortic. Sci. Biotechnol. 77:441-445.

40. Reuveni, M., Sheglov, D., and Cohen, Y. 2003. Control of moldy-core decay in apple fruits by b-aminobutyric acids and potassium phosphites. Plant Dis 87:933-936.

41. Roos, G. H. P., Loane, C., Dell, B., and Hardy, G. E. S. J. 1999. Facile high performance ion chromatographic analysis of phosphite and phosphate in plant samples. Commun. Soil Sci. Plant Anal. 30:2323-2329.

42. Rosenberger, D. A., Meyer, F. W., and Rugh, A. L. 2008.Effectiveness of ProPhyt used alone or with Captan, Topsin M, or Pristine to control summer diseases of apples. PF010 Plant Dis. Manage. Rep. 3:1-3.

43. Saindrenan, P., Brachietto, T., Avelino, and J., Bompeix, G. 1988. Effect of phosphite on phytoalexin accumulation in leaves of cowpea infected with Phytophthora cryptogea. Physiol. Mol. Plan Pathol. 32:425-435.

44. Schirra, M., D’Aquino, S., Cabras, P., and Angioni, A. 2011. Control of postharvest diseases of fruit by heat and fungicides: efficacy, residue levels, and residue persistence. A review. J. Agric. Food Chem. 59:8531-8542. 
45. Smilanick, J. L., Brown, G. E., and Eckert, J. W. 2006. Postharvest citrus diseases and their control. Pages 339-396 in: Fresh Citrus Fruits, Second ed. W. F. Wardowski, W. M. Miller, D. J. Hall, and W. Grierson, eds. Florida Science Source, Inc., Longboat Key, FL.

46. Smilanick, J. L., Mansour, M. F., Margosan, D. A., Mlikota Gabler, F., and Goodwine, W. R. 2005. Influence of $\mathrm{pH}$ and $\mathrm{NaHCO} 3$ on effectiveness of imazalil to inhibit germination of Penicillium digitatum and to control postharvest green mold on citrus fruit. Plant Dis. 89:640-648.

47. Smilanick, J. L., Mansour, M. F., Mlikota Gabler, F., and Goodwine, W. R., 2006. The effectiveness of pyrimethanil to inhibit germination of Penicillium digitatum and to control citrus green mold after harvest. Postharvest Biol. Technol. 42:75-85.

48. Smilanick, J. L., Mansour, M. F., Mlikota Gabler, F., and Sorenson, D. 2008. Control of citrus postharvest green mold and sour rot by potassium sorbate combined with heat and fungicides. Postharvest Biol. Technol. 47:226-238.

49. Smilanick, J. L., Margosan, D. A., Mlikota Gabler, F., Usall, J., and Michael, I. F. 1999. Control of citrus green mold by carbonate and bicarbonate salts and the influence of commercial practices on their efficacy. Plant Dis.
83:139-145.

50. Smilanick, J. L., Michael, I. F., Mansour, M. F., Mackey, B. E., Margosan, D. A., Flores, D., and Weist, C. F. 1997. Improved control of green mold of citrus with imazalil in warm water compared with its use in wax. Plant Dis. 81:1299-1304.

51. Smilanick, J. L., and Sorenson, D. 2001. Control of postharvest decay of citrus fruit with calcium polysulfide. Postharvest Biol. Technol. 21:157-168.

52. Smillie, R., Grant, B. R., and Guest, D. 1989. The mode of action of phosphite: evidence for both direct and indirect modes of action of three Phytophthora spp. in plants. Phytopathology 79:921-925.

53. Spalding, D. H., and Lieberman, M. 1965. Factors affecting the production of ethylene by Penicillium digitatum. Plant Physiol. 40:645-648.

54. Thao, H. T. B., and Yamakawa, T. 2009. Phosphite (phosphorous acid): fungicide, fertilizer or bio-stimulator? Soil Sci. Plant Nutr. 55:228-234.

55. US EPA. 2006. Title 40: Protection of Environment, Part 180. Code of Federal Reg. 71:49373.

56. Yamazaki, Y., and Ninomiya, T. 1996. Determination of imazalil residues in lemon by gas chromatography with nitrogen-phosphorus detection. J. Assoc. Off. Anal. Chem. Int. 79:787-790 